2016-03

\title{
Institutions and corporate capital structure in the MENA region
}

\author{
Belkhir, M
}

http://hdl.handle.net/10026.1/4507

10.1016/j.ememar.2016.01.001

Emerging Markets Review

Elsevier BV

All content in PEARL is protected by copyright law. Author manuscripts are made available in accordance with publisher policies. Please cite only the published version using the details provided on the item record or document. In the absence of an open licence (e.g. Creative Commons), permissions for further reuse of content should be sought from the publisher or author. 


\title{
Institutions and corporate capital structure in the MENA region
}

\author{
Mohamed Belkhir ${ }^{\mathrm{a}, *}$, Aktham Maghyereh $^{\mathrm{a}}$, Basel Awartani ${ }^{\mathrm{b}}$ \\ ${ }^{a}$ UAE University, College of Business \&' Economics, United Arab Emirates \\ ${ }^{\mathrm{b}}$ University of Plymouth, Plymouth, Graduate School of Management \& Plymouth Business School, United Kingdom
}

\section{A R T I C L E I N F O}

\section{Article history:}

Received 11 March 2015

Received in revised form 3 January 2016

Accepted 4 January 2016

Available online 11 January 2016

\section{JEL classification:}

F30

G18

G32

Keywords:

Capital structure

Leverage

MENA

Institutions

Financial development

\section{A B S T R A C T}

This paper provides novel evidence on firm- and country-level determinants of firm capital structure decisions in the MENA region. Using a sample of 444 listed firms from ten countries, over the 2003-2011 period, we find that MENA firms have target leverage ratios towards which they adjust over time. Yet, the speed of adjustment varies from one country to another. Our findings also suggest that some firm-level factors are associated with leverage consistent with the trade-off and pecking order theories of capital structure. We further find robust evidence that better institutional quality leads firms to use more debt.

(c) 2016 Elsevier B.V. All rights reserved.

\section{Introduction and motivation}

An extensive body of research has been dedicated to answering Myers (1984) question "How do firms choose their capital structures?" Most studies have examined the capital structure issue in samples of firms from a single country, typically the United States. Nevertheless, more recently, several studies have extended their geographical scope and investigated the determinants of capital structure in international samples covering firms from different countries. Examples of such studies are Booth et al. (2001) for developing countries, Bancel and Mittoo (2004) for European countries, Antoniou et al. (2008) for five developed countries, Getzmann et al. (2014) for Asian countries, and De Jong et al. (2008), Gungoraydinoglu and Öztekin

\footnotetext{
* Corresponding author at: UAE University, College of Business \& Economics, Building H3, Office 1060, United Arab Emirates. E-mail addresses: m.belkhir@uaeu.ac.ae (M. Belkhir), a.almaghaireh@uaeu.ac.ae (A. Maghyereh), basel.awartani@plymouth.ac.uk (B. Awartani).
} 
(2011), Fan et al. (2012), and Oztekin and Flannery (2012) for samples of countries from different parts of the world. A close look into these studies suggests two major remarks. The first is that some firm-level factors are associated with corporate leverage in a similar way no matter what country or region the firm is located in. For instance, consistent with the trade-off theory of capital structure, firm size and asset tangibility are positively associated with leverage ratios across most, if not all, of these studies. Likewise, in line with the predictions of the pecking order theory of capital structure, firm profitability tends to be negatively associated with leverage ratios in the majority of these studies. The second is that country-level factors play a significant role in determining firm leverage. In particular, the nature and quality of a country's institutions impact firm optimal (target) leverage. Furthermore, such institutions have been shown to affect the speed at which firms in a specific country adjust towards their target leverage.

In this paper, we extend the aforementioned literature to the Middle East and North Africa region (MENA hereafter) and try to answer two questions: (1) is firm leverage in MENA countries determined by the same factors as those identified in other parts of the world? (2) Do institutional environments in MENA countries affect firms' capital structures, and if so, how? To answer these questions we use a sample of firms from ten MENA countries, which are Bahrain, Egypt, Jordan, Kuwait, Morocco, Oman, Qatar, Saudi Arabia, Tunisia, and the UAE. To the best of our knowledge, this is the first comprehensive study of capital structure choices in the MENA region. Not only there is no prior research on firm capital structure decisions dedicated specifically to this region, but also studies using international samples tend to exclude countries from the region from their coverage. For instance, De Jong et al. (2008), Fan et al. (2012), and Oztekin and Flannery (2012) include firms from 37 countries to examine capital structure choices, but none of these countries is from the MENA region. We fill this gap in the literature and shed light on an important firm decision - financing decision - in a growing, but understudied, region.

Examining firm financing choices in the MENA region is of utmost importance as the region's countries have been going, for more than two decades now, through reforms aiming at moving away from centrally planned economies to market-oriented ones. Firms are thereby supposed to behave consistent with the goal of value maximization. It is thus of interest to investigate whether their financing decisions are determined by the same factors observed in advanced countries where firms have been operating according to the goal of value maximization for a long time, such as the U.S. and Western European countries. Furthermore, there is steady integration of the region's financial markets in the global financial system. For instance, in May 2014, index compiler MSCI has upgraded stock markets of the United Arab Emirates and Qatar from frontier to emerging market status, which is expected to increase capital flows into these markets as well as international investors' focus on them. Such a move should, in turn, drive listed firms in those two markets to adopt best practices in terms of investment and financing decisions. It should also provide further incentives to other stock markets in the region to adopt reforms and regulations that could promote their status from frontier to emerging. Besides these positive developments, firms located in the MENA countries continue to face a relatively weak institutional environment where investor protection is weak, bankruptcy regimes are deficient, and property rights are insecure. This is likely to affect their access to external capital, and, thereby, to determine their optimal financial structures as well as the speed at which they revert back to such optimal structures following shocks.

To examine capital structure and its firm- and country-level determinants in the MENA region, we use a sample of 444 listed firms from ten countries, over the 2003-2011 period, or 3717 firm-year observations. Our findings suggest that the average firm in the MENA region has a book leverage ratio of $39 \%$ (median: $36.8 \%$ ) and a market leverage ratio of $33.4 \%$ (27.5\%), which is comparable to leverage ratios in other developing countries, reported in Booth et al. (2001) and Fan et al. (2012), but also to leverage ratios in the five most developed countries in the world, reported in Antoniou et al. (2008). Using a partial adjustment model of firm leverage that accounts for the dynamic nature of capital structure, we find evidence that firms in MENA countries have target capital structures towards which they adjust over time. We further find that the speed of adjustment towards target leverage varies from one country to another, possibly reflecting differences in the nature and quality of the institutional environments across countries, which, in turn, affect adjustment costs. Our results also suggest that traditional firm-level determinants of leverage tend to affect debt ratios in MENA countries in line with standard capital structure theories, and consistent with the findings of prior research on countries from other parts of the world. For instance, we find evidence of a consistent and strong positive impact of firm size and asset tangibility on leverage and a negative impact of profitability and growth opportunities on leverage. Our cross-country analysis of the potential impact of the institutional framework 
on firm leverage shows that firms located in countries with more developed financial systems, more regulatory effectiveness, and stronger rule of law use more debt. In a further analysis, we also show that better quality institutions attenuate the impact of size and asset tangibility on leverage.

Our study contributes to two literatures. First, we extend research on cross-country differences in firm capital structure by presenting new evidence from a different geographical region that the level of a country's financial development and the quality of its public governance impact firm financing choices. We further show that the quality of a country's institutions has not only a direct but also an indirect influence on firm capital structure. In this regard, our research intersects with evidence that capital structure depends upon a country's legal system (Bancel and Mittoo, 2004; Fan et al., 2012), creditor rights' protection (De Jong et al., 2008; Cho et al., 2014), corruption (Fan et al., 2012), and whether an economy is market- or bank-based (Antoniou et al., 2008). Our paper presents further evidence on the benefits of improving a country's institutional quality.

Second, we contribute to the build-up of a literature that examines firm financing choices in emerging markets whose institutional frameworks are generally different from those underpinning Western - especially U.S - models of capital structure. Specifically, our study adds to Ebrahim et al. (2014), who document evidence of the influence of political patronage on Malaysian firms' capital structures, Deesomak et al. (2004), who show that legal, financial, and institutional environments influence capital structure decisions of firms from the Asia Pacific region, Chen (2004) whose findings suggest that the capital structure choices of Chinese firms seem to follow a "new Pecking Order", and Cespedes et al. (2010) who report that Latin American firms exhibit higher leverage than expected because their ownership concentration is higher than those in developed countries. We extend this literature by shedding light on several issues related to capital structure in a region characterized by a different institutional environment and that has received little, if any, attention in the capital structure literature.

The remainder of the paper is organized as follows. Section 2 provides a brief review of capital structure theories, describes the major characteristics of the institutional environment with a potential impact on capital structure choices in the MENA region, and discusses predictions of firm- and country-level effects on leverage. Section 3 describes our data set and empirical method. Section 4 presents empirical results. Finally, Section 5 concludes the paper.

\section{Institutions and capital structure decisions in MENA}

In this section, we first, provide a brief review of the theories of capital structure which we rely on to study leverage decisions in the MENA region. We, then, provide a description of the quality of the institutional environment in MENA countries. Finally, we use the insights of these theories and the characteristics of the institutional settings to predict the effects of firm- and country-factors on leverage.

\subsection{Capital structure theories}

The major theories of capital structure are the static trade-off, pecking order, and market timing models (Huang and Ritter, 2009). In contrast to the irrelevance theorem of Modigliani and Miller (1958), the static trade-off theory argues that firms have optimal debt ratios, which they need to hold to maximize their values. Specifically, in the presence of capital market frictions, firms have optimal debt ratios that result from a trade-off between the benefits and costs of debt. Such costs and benefits have various sources, such as the deadweight costs of bankruptcy, agency costs, and tax benefits. In contrast to the trade-off theory, the pecking order theory of capital structure suggests that a firm has no specific leverage ratio that maximizes its value. In the pecking order framework, information asymmetry induces managers to believe that equity issues will be underpriced by the market (Myers and Majluf, 1984). This, in turn, discourages them - i.e., managers - from issuing new equity as long as they can finance their new investments with less adverse selection-prone securities, such as internal funds and debt. This preference order of financing sources suggests that a firm's observed leverage ratio reflects its past profitability and investment opportunities. The market timing theory also rejects the idea of target leverage. It rather argues that a firm's observed leverage reflects managers' past attempts to time the equity market by issuing overvalued stock shares (Baker and Wurgler, 2002). In the words of Baker and Wurgler, “...low leverage firms are those that raised funds when their market 
valuations were high, as measured by the market-to-book ratio, while high leverage firms are those that raised funds when their market valuations were low" (p. 2).

While the above-discussed theories have contributed significantly to our understanding of some of the factors determining firm leverage, they also face significant challenges as stand-alone models of capital structure (Denis, 2012). To overcome part of these challenges, more recent literature has emphasized dynamic models in which firms have target leverage ratios towards which they attempt to adjust to maximize their values. This adjustment can be slow or fast depending on the magnitude of transaction and security issuance costs - adjustment costs. This implies that in the presence of large adjustment costs, a firm's observed leverage can deviate significantly from its target. Numerous empirical studies have accounted for the potentially dynamic nature of capital structure, and attempted to test whether firms have leverage targets and if so, what is the speed at which they adjust towards such targets (e.g., Fama and French, 2002; Flannery and Rangan, 2006; Lemmon et al., 2008; Huang and Ritter, 2009).

\subsection{MENA region institutional environment}

In this section, we provide a description of the quality of the legal and contractual environment in MENA countries, which may help in predicting and understanding capital structure decisions of firms located in this region. In this discussion, we approach the region as a whole and emphasize institutions with implications to firms' access to debt capital. We particularly focus on the quality of public governance, the state of insolvency and information sharing regimes, and the financial sector.

\subsubsection{Public governance}

The quality of public governance is one of the factors that determine economic agents' confidence that their claims and property rights, including financial assets, are well protected against expropriation by both the government and private parties. In well governed countries, the rule of law prevails over any other rule - such as of persons or political parties - and sovereign institutions are reliable and believed to strive towards effective protection of property rights and contract enforcement. Hence, lenders have better confidence that their capital will be recovered even in extreme cases of debtor default and may, thus, be more willing to extend credit at more favorable terms. While MENA countries strive continuously to improve their public governance, they remain, on average, among the countries where institutions suffer from many deficiencies. Reports by international organizations regularly observe that, in many countries, the political system continues to hold sway over the judicial system, the media, and the legislative system. Moreover, it is usually mentioned that in these countries, access to public services as well as to business opportunities is often dependent on nepotism, tribal affinity, patronage, or money. The result is rampant corruption, poor legal enforcement of contracts, and widespread property rights' insecurity, which negatively impacts firms' access to external finance in the region. ${ }^{1}$

\subsection{Insolvency regimes, collateral, and credit information sharing systems}

A country's insolvency regime - bankruptcy law -, typically, determines the extent to which creditors can repossess collateral, reorganize the defaulting borrower, and recover a substantial part of the loaned capital in case of default. This is not without implications for firms' access to external finance. For instance, Araujo et al. (2012) find that reforming bankruptcy law in Brazil, in a way that enhanced creditors' rights in cases of debtor default, resulted in increases of $10 \%$ and $23 \%$ in the amount of firm total debt and long-term debt, respectively. Djankov et al. (2007) report a wide variation in creditor rights across countries, with implications for access to credit by private businesses; countries where creditors enjoy better legal protection have a greater ratio of private sector credit to GDP.

In MENA countries, one of the major issues that firms and investors face is the legal framework that defines insolvency and collateral regimes and creditor rights. Bankruptcy systems in MENA countries remain weak in settling insolvency cases through reorganization or liquidation. For instance, according to the Doing Business report of the World Bank (2012), creditors in these countries can expect to recover, on average, only 32.7

\footnotetext{
${ }^{1}$ See, for instance, the MENA Quarterly Economic Brief, issued in July 2014, for evidence on poor public governance in some MENA countries.
} 
cents on a dollar from insolvent firms; a recovery rate which is lower than in any other region, except Sub-Saharan Africa. ${ }^{2}$ Likewise, insolvency resolution is highly costly in MENA countries as it amounts to $14 \%$ of the value of the debtor's estate, compared with $9 \%$ in OECD high-income countries. Moreover, the MENA region average time to resolve insolvency is too long - about 3.5 years. Collateral legal regimes are another concern for creditors in MENA countries. While statistics reported by the Enterprise Survey of the World Bank show that access to credit is almost always contingent upon the availability of collateral, most MENA countries suffer from the lack of reliable collateral regimes. ${ }^{3}$ As documented by Haselmann et al. (2010), the quality of collateral law is an important determinant of bank lending. Yet, in most MENA countries, the law does not recognize non-possessory interests in movable collateral and does not establish clear priority rules between secured creditors after a debtor becomes in default. Consequently, MENA banks are said to face problems related to secured lending, especially in terms of registration, enforcement, and liquidation particularly for movable collateral (e.g., Alvarez de la Campa, 2011).

Effective information sharing and credit reporting systems that provide lenders positive and negative data on borrowers also support access to credit as they alleviate one of the major problems facing credit institutions - information asymmetry (See for instance, Jappelli and Pagano (2002) for empirical evidence). Information sharing systems in MENA credit markets are, by many standards, under-developed. While credit reporting systems all over the world rely more and more on private credit bureaus (PCB), thought to collect and provide more comprehensive information about borrowers, those of MENA countries are still composed mainly of public credit registries (PCR), characterized by a lower level of depth of credit information. According to Madeddu (2010), two-thirds of MENA countries still entirely rely on PCRs, which is a higher percentage compared to all other geographical regions, except for Sub-Saharan Africa. While improving, the coverage of the population of borrowers - individuals and firms - is also still low compared to other regions (Business, 2013).

\subsection{Financial system}

It is widely believed that financial system development reduces the cost of external finance to firms (e.g., Rajan and Zingales, 1998). MENA countries have engaged, over the last two decades, in a series of liberalization measures aimed at developing their financial sectors (Ben Naceur et al., 2008; Ben Naceur and Omran, 2011). Among the notable measures taken in this direction are the ending of government controls on deposit and lending rates and on credit allocation, the removal of high reserve requirements, and the permission granted to foreign investors to acquire shares through the stock market (liberalizing stock markets). These measures are expected to enhance financial development and, thereby to promote firms' access to external finance. Yet, most assessments agree that these endeavors are far from having achieved the desired goals (e.g., Bourgain et al., 2012; Guyot et al., 2014). Ben Naceur and Omran (2011) note that "Despite these reforms, security markets in the MENA region are still underdeveloped, with a limited number of listed companies, low free-float of shares, and thin trading" (p. 4). Only a handful of countries, such as the GCC countries, have relatively developed and efficient bank sectors (Creane et al., 2004). In most of the other countries, however, the banking sector continues to be characterized by a heavy involvement of government-owned banks, known for lower efficiency in allocating credit and for deficient risk management systems. Likewise, in most of these countries, the banking sector is highly concentrated, and barriers to entry of new banks are typically high (Turk-Ariss, 2009; Anzoategui et al., 2010).

\subsection{Predictions}

\subsubsection{Leverage and firm-level factors}

To examine firm capital structure decisions in MENA countries, we use a set of common factors (Harris and Raviv, 1991; Frank and Goyal, 2009) identified in most capital structure studies as having a significant

\footnotetext{
2 The recovery rate is $68.2 \%$ in OECD high-income countries.

3 The Enterprise Survey shows that $72.2 \%$ of loans granted in MENA countries require collateral, and that the value of collateral needed represents an average of $176.7 \%$ of the amount of the requested loan (Based on datasets available on www.enterprisesurveys.org, accessed on March 02, 2014).
} 
influence on firm leverage. In what follows we discuss these factors and our expectations on their impact on corporate leverage given the institutional and contracting environments that characterize MENA countries.

2.5.1.1. Firm size. Larger, more diversified, firms are expected to have higher target leverage ratios because they have less volatile earnings and, subsequently, face lower expected bankruptcy costs (e.g., Rajan and Zingales, 1995; Fama and French, 2002). Moreover, larger firms may have better access to capital markets (Fama and French, 2002), and thereby Face lower costs of raising additional debt, all else equal. Kurshev and Strebulaev (unpublished manuscript) also argue that, in the presence of non-trivial fixed costs of raising external funds, large firms have cheaper access to outside financing. The trade-off theory, thus, predicts a positive effect of firm size on debt. Size may also be a proxy for information asymmetry between insiders and outside investors. According to Fama and Jensen (1983), larger firms suffer from less information asymmetry compared to smaller ones. As such, they are less prone to adverse selection problems, and are expected to have easier access to external finance from both debt and equity capital markets. The pecking order theory, thus, does not predict a clear-cut relation between size and leverage. As is standard in the literature, we measure firm size by the natural logarithm of total assets (SIZE). In MENA countries where institutions with an impact on firms' access to credit suffer from many deficiencies, we expect that access to debt capital will be much easier for larger firms, for the latter have the connections and the reputational capital, necessary for access to credit in a weak institutional and contracting environment. In a cross-country setting, we also expect that the positive association between size and leverage attenuates in countries with relatively better quality institutions.

2.5.1.2. Tangibility. The availability of tangible assets, such as property, plant, and equipment, can improve the recovery rates for creditors in cases of borrower default. As a result, this lowers expected bankruptcy costs and enhances lenders' willingness to supply credit. Additionally, tangible assets can reduce agency costs of debt by preventing shareholders from substituting high-risk investments for low-risk ones (Frank and Goyal, 2009). By reducing expected bankruptcy costs and agency costs, tangible assets are expected to raise a firm's target leverage. In the pecking order model, tangible assets can be associated with low information asymmetry. This implies that the cost of issuing equity is relatively lower for firms with more tangible assets, holding all else equal. As a result, firms with more tangible assets are expected to have less leverage. Across MENA countries, bankruptcy laws are weakly protective of lenders and property rights' security is low. It follows that creditors fear expropriation and are more likely to require collateral to extend credit. Furthermore, poor collateral regimes do not enable firms and lenders to rely on assets other than tangible ones - mostly real estate assets as loan collateral. We, thus, expect tangible assets to have a strong and consistent positive impact on firm leverage across MENA countries. We also expect this positive impact to shrink in countries with comparatively better institutions - where collateral typically plays a less important role in lenders' willingness to extend credit. We use the ratio of net fixed assets to total assets as a proxy for tangibility (TANG).

2.5.1.3. Profitability. More profitable firms face less expected bankruptcy costs. Moreover, if not shielded with important interest payments, these firms may end up paying higher amounts of corporate taxes (Modigiliani and Miller, 1963). From an agency perspective, more profits should also lead to the use of more debt as a mechanism to curb managers' distorted incentives resulting from the availability of free cash flow (Jensen, 1986). Therefore, in a trade-off framework, more profitable firms are likely to increase their target leverage ratios. The basic model of the pecking order theory suggests that firms have a preference for internal funds over external ones to finance their investments. Thus, contrary to the trade-off theory, the pecking order theory predicts that, holding investments fixed, leverage should be lower for more profitable firms. In an environment where institutions are not well developed to help mitigate information asymmetry between lenders and firms, such as in MENA countries, raising debt can be costly to firms. Thus, firms resort less to raising debt as long as their profitability allows them to meet their investment needs. We, thus, expect that more profitable firms have less leverage within each of our MENA countries. We use the ratio of operating income to assets as our measure of profitability (PROF).

2.5.1.4. Taxes. When interest is tax deductible, the greater the tax rates a firm faces and the more benefits it derives from using debt; greater interest payments result in more tax savings. The trade-off theory, thus, predicts that firms facing greater tax rates on profits will use more leverage. We use the ratio of current income 
taxes to income before taxes as a proxy for tax rates (TAX) and expect a positive cross-sectional correlation between TAX and firm leverage.

2.5.1.5. Bankruptcy risk. The trade-off theory implies that firms who are far away from financial distress will have higher leverage because they enjoy low expected costs of bankruptcy. To control for the potential impact of financial distress on corporate leverage, we include Altman's Z-score as modified by MacKie-Mason (1990) in the leverage regression equations. Altman's Z-score is a measure of the ex ante probability of distress (Graham, 2000), with higher values indicating a lower probability of distress. According to the trade-off model, we should observe a positive association between Z-score and leverage.

2.5.1.6. Liquidity. Firms with more liquid assets face lower bankruptcy costs, which enables them to raise more debt. More liquidity - free cash flow - is also a source of agency costs; firms with more liquidity, therefore, gain from using more debt to discipline their managers. Hence, according to the trade-off theory, more liquid assets will result in more leverage. However, in the pecking order theory, more liquid assets imply less information asymmetry and, hence, a better ability to raise equity. This implies that higher asset liquidity is conducive to less leverage. We use the ratio of current assets to total assets as a proxy for liquidity (LIQ).

2.5.1.7. Growth opportunities. According to the agency model of capital structure, firms with more growth opportunities should have less leverage. First, holding profitability fixed, these firms suffer less from the free cash flow agency problem, which reduces the benefit of using debt as a mechanism to discipline managers. Second, in the presence of growth opportunities, firms have incentives to use less risky debt, especially long-term debt, to lower the agency cost associated with an investment policy where some valuable investment opportunities are foregone (Myers, 1977; Barnea et al., 1981). Third, high growth firms which are more prone to information asymmetry may suffer more from the asset substitution agency conflict where insiders substitute high risk investments for low-risk ones. According to this view, high growth firms can reduce their agency costs by having less debt (Jensen and Meckling, 1976). The pecking order theory predicts that growth firms, which typically suffer from more information asymmetry, will accumulate more debt, holding profitability fixed. Based on prior literature (e.g., Adam and Goyal, 2008; Frank and Goyal, 2009), we use the market-to-book ratio to proxy for growth opportunities (GROWTH). In MENA countries where information asymmetry and property rights' and creditors' protection are major concerns, the sign of the within country cross-sectional effect of GROWTH on leverage will depend on which effect - agency effect or pecking order effect - prevails over the other.

\subsubsection{Leverage and MENA institutional factors}

To capture the role of institutional quality in firm leverage decisions across the MENA region, we rely on several indicators of the quality of public governance and financial development. While a complex and multifaceted concept, good public governance is commonly captured by some of its critical dimensions, such as the rule of law, public sector efficiency, control of corruption, and democracy. We use three indicators which capture three different dimensions of the quality of public governance: rule of law, regulatory effectiveness, and corruption. ${ }^{4}$

2.5.2.1. Rule of Law. The rule of law refers to the preeminence of law in governing behavior within a society, including of government institutions and officials. We measure the extent to which a MENA country abides by the rule of law by the rule of law index developed by the World Bank (RL). This index reflects perceptions of the extent to which agents have confidence in and abide by the rules of society, and in particular the quality of contract enforcement, property rights, the police, and the courts, as well as the likelihood of crime and violence. This index ranges from -2.5 (weak rule of law) to 2.5 (strong rule of law). In countries where institutions and individuals abide by the rule of law, investors are less worried to be expropriated by managers and firms. This is likely to enhance their willingness to extend credit to firms at relatively better terms. We, therefore, expect that corporate leverage increases in the rule of law.

\footnotetext{
${ }^{4}$ Ideally, one could have also used indicators that measure the state of bankruptcy regimes, creditor rights, investor protection, contract enforcement, etc. However, when they are available for our sample countries, these indicators do not exhibit sufficient time-series and cross-country variation to ensure sound empirical estimations.
} 
2.5.2.2. Regulatory Effectiveness. Regulatory effectiveness refers to a government's capability to enact and implement policies and regulations that enhance the business climate and encourage entrepreneurship, production, and exchange of goods and services. We use the World Bank's regulatory quality index as a proxy for a country's regulatory effectiveness. This index captures perceptions of the ability of the government to formulate and implement sound regulations regarding the acquisition of property, licensing of new businesses, hiring of workers, importing factors of production, exporting output or capital, contracting with suppliers for needed inputs, payment of taxes, government licenses and fees, and so forth. The index ranges from -2.5 (weak effectiveness) to 2.5 (strong effectiveness). We label this measure RE and expect it to be positively associated with firm leverage.

2.5.2.3. Corruption. Corruption can make it difficult to conduct business effectively, and may discourage firms from raising debt capital due to the costly bribes that they need to disburse to be granted loans. In such a case, the more corruption a country has and the lower the corporate leverage will be. Yet, an alternative view suggests that corruption could be an efficient "lubricant" against stringent economic regulation and red-tape. This could be especially true for access to credit in countries where the contractual environment is not business friendly and where banks are reluctant to extend credit at easy terms, as is the case in most MENA countries. By bribing bank officers, firms can get around regulations and stringent bank requirements related to collateral, default risk, etc. In such case, more corruption should lead to the use of more debt, ceteris paribus. We use the World Bank index of corruption as a proxy for a country's control of corruption (CORR). The index ranges from -2.5 (weak control of corruption) to 2.5 (strong control of corruption). Whether more corruption leads to more or less corporate leverage is an empirical issue which we leave to the empirical estimations to uncover.

2.5.2.4. Financial development. Financial development facilitates firms' access to external finance, especially through enhancing the quality of information. Rather than considering whether a country has a market- or a bank-based financial system, in this paper, we take the view that it is the level of development of the whole financial system represented by both equity markets and financial intermediaries that matters to firms financing decisions. Subsequently, we measure financial development (FD) by an indicator that captures size, activity, and efficiency of both financial intermediaries and markets. This indicator developed by Demirguc-Kunt and Levine (1999) and Levine (2002) is a principal component of finance activity, size and efficiency where finance activity is the logarithm of the total value traded ratio times the private credit ratio, financial size is the logarithm of the market capitalization ratio times the private credit ratio, and financial efficiency is the logarithm of the total value traded ratio divided by overhead costs. Greater values of FD indicate a more developed financial system. Whether greater financial development leads to the use of more debt or equity is therefore an empirical issue.

Following Demirguc-Kunt and Maksimovic (1996), our multivariate analysis also controls for two macroeconomic factors: the inflation rate (INF) and GDP annual growth rate (GDPG).

\section{Data and empirical method}

\subsection{Data}

Our firm-level data are collected from the Fitch-IBCA Worldscope database. Macroeconomic data - GDP and inflation rate - are obtained from the IMF's International Financial Statistics, whereas country-level institutional variables are obtained from various sources, such as the Financial Structure Database and the Governance Indicators Database of the World Bank, and the Heritage Foundation. Variables used in the analysis, their descriptions, and sources are reported in Table 1.

Our sample covers firms from 10 MENA countries. The countries are Bahrain, Egypt, Jordan, Kuwait, Morocco, Oman, Qatar, Saudi Arabia, Tunisia, and the UAE. ${ }^{5}$ Thus, six of our sample countries are members

\footnotetext{
${ }^{5}$ The choice of these ten countries is dictated by the availability of data in the Worldscope database. In fact, in many other countries of the region, there are only a few or no reported companies in the database, which led to their exclusion from our sample.
} 
Table 1

Description of the variables and sources.

\begin{tabular}{|c|c|c|}
\hline Variable & Description & Source \\
\hline \multicolumn{3}{|c|}{ Panel A: Variables used in the main analysis } \\
\hline \multicolumn{3}{|c|}{ Leverage measure } \\
\hline $\begin{array}{l}\text { Book value total } \\
\text { debt ratio (BVD) }\end{array}$ & Total debt to total assets & Fitch-IBCA Worldscope \\
\hline $\begin{array}{l}\text { Market value total } \\
\text { debt ratio (MVD) }\end{array}$ & Total debt to the market value of equity plus the book value of debt & Fitch-IBCA Worldscope \\
\hline \multicolumn{3}{|l|}{ Firm-level variables } \\
\hline Size (SIZE) & Natural $\log$ of total assets & Fitch-IBCA Worldscope \\
\hline Tangibility (TANG) & Net fixed assets to total assets & Fitch-IBCA Worldscope \\
\hline Profitability (PROF) & Operating income to total assets & Fitch-IBCA Worldscope \\
\hline Tax shield (TAX) & Current income taxes to Income before taxes & Fitch-IBCA Worldscope \\
\hline $\begin{array}{l}\text { Distance from } \\
\text { bankruptcy (Z- } \\
\text { score) }\end{array}$ & $\begin{array}{l}\text { Measured by } Z \text {-score }=3.3(\mathrm{EBIT} / \text { total assets })+1.0 \text { (sales/total } \\
\text { assets) }+1.4 \text { (retained earnings/total assets) }+1.2 \text { (working capital/total } \\
\text { assets). Greater values indicate lower likelihood of bankruptcy. }\end{array}$ & $\begin{array}{l}\text { Fitch-IBCA Worldscope, } \\
\text { authors' calculations }\end{array}$ \\
\hline Liquidity (LIQ) & Current assets to total assets & Fitch-IBCA Worldscope \\
\hline $\begin{array}{l}\text { Growth } \\
\text { opportunity } \\
\text { (GROWTH) }\end{array}$ & The market value of equity plus the book value of debt to total assets & Fitch-IBCA Worldscope \\
\hline \multicolumn{3}{|l|}{ Economic variables } \\
\hline $\begin{array}{l}\text { GDP growth } \\
\text { (GDPG) }\end{array}$ & Growth rate of real of GDP & $\begin{array}{l}\text { IMF's International } \\
\text { Financial Statistics }\end{array}$ \\
\hline Inflation (INF) & Rate of increase in CPI & $\begin{array}{l}\text { IMF's International } \\
\text { Financial Statistics }\end{array}$ \\
\hline \multicolumn{3}{|l|}{ Institutional variables } \\
\hline $\begin{array}{l}\text { Financial } \\
\text { development (FD) }\end{array}$ & $\begin{array}{l}\text { Financial system development is a principal component of finance activity, } \\
\text { size and efficiency where finance activity is the logarithm of the total value } \\
\text { traded ratio times the private credit ratio, financial size is the logarithm of } \\
\text { the market capitalization ratio times the private credit ratio, and financial } \\
\text { efficiency is the logarithm of the total value traded ratio divided by } \\
\text { overhead costs. Suggested by Demirguc-Kunt and Levine (1999) and Levine } \\
\text { (2002). }\end{array}$ & $\begin{array}{l}\text { Financial structure } \\
\text { database } \\
\text { (World Bank), authors' } \\
\text { calculations }\end{array}$ \\
\hline $\begin{array}{l}\text { Regulatory } \\
\text { effectiveness (RE) }\end{array}$ & $\begin{array}{l}\text { Index reflects perceptions of the ability of the government to formulate and } \\
\text { implement sound regulations regarding the acquisition of property, } \\
\text { licensing of new businesses, hiring of workers, importing factors of } \\
\text { production, exporting output or capital, contracting with suppliers for } \\
\text { needed inputs, payment of taxes, government licenses and fees, and so } \\
\text { forth. The index ranges from }-2.5 \text { (weak effectiveness) to } 2.5 \text { (strong } \\
\text { effectiveness). }\end{array}$ & $\begin{array}{l}\text { Governance indicators } \\
\text { database } \\
\text { (World Bank) }\end{array}$ \\
\hline Rule of Law (RL) & $\begin{array}{l}\text { Index reflects perceptions of the extent to which agents have confidence in } \\
\text { and abide by the rules of society, and in particular the quality of contract } \\
\text { enforcement, property rights, the police, and the courts, as well as the } \\
\text { likelihood of crime and violence. The index ranges from - } 2.5 \text { (weak law) to } \\
2.5 \text { (strong law). }\end{array}$ & $\begin{array}{l}\text { Governance indicators } \\
\text { database } \\
\text { (World Bank) }\end{array}$ \\
\hline Corruption (CORR) & $\begin{array}{l}\text { Index reflects perceptions of the extent to which public power is exercised } \\
\text { for private gain, including both petty and grand forms of corruption, as well } \\
\text { as "capture" of the state by elites and private interests. The index ranges } \\
\text { from }-2.5 \text { (weak control of corruption) to } 2.5 \text { (strong control of } \\
\text { corruption). }\end{array}$ & $\begin{array}{l}\text { Governance indicators } \\
\text { database } \\
\text { (World Bank) }\end{array}$ \\
\hline \multicolumn{3}{|c|}{ Panel B: Alternative variables used in the robustness tests } \\
\hline $\begin{array}{l}\text { Long-term debt ratio } \\
\quad \text { (LTDR) }\end{array}$ & $\begin{array}{l}\text { The ratio of long-term debt (maturing more than one year) to total debt. } \\
\text { Total debt is the sum of long-term debt and debt in current liabilities. }\end{array}$ & $\begin{array}{l}\text { Fitch-IBCA Worldscope, } \\
\text { authors' calculations }\end{array}$ \\
\hline $\begin{array}{l}\text { Non-debt tax shields } \\
\text { (TAX1) }\end{array}$ & The ratio of depreciation and amortization to total asset & $\begin{array}{l}\text { Fitch-IBCA Worldscope, } \\
\text { authors' calculations }\end{array}$ \\
\hline
\end{tabular}

Notes: This table describes the variables used in the paper.

of the Gulf Cooperation Council characterized by oil-export-based economies. We use annual data over the period 2003-2011. Following prior research, we exclude all financial firms whose capital structure decisions obey to other factors. We require that firms have at least three consecutive years of available data over the sample period to be included in the sample. Moreover, we exclude firms with negative book equity. Our 
final sample consists of 444 firms making up a total of 3717 firm-year observations. ${ }^{6}$ We winsorize all firmlevel variables at the 1 st and 99th percentiles to mitigate the potential impact of outliers on the analysis.

\subsection{Empirical method}

In this study, we use two widely used measures of firm capital structure: the total book-debt ratio (BVD) a measure of book leverage - defined as the ratio of total debt to book value of assets and the total marketdebt ratio (MVD) - a measure of market leverage -defined as the ratio of total debt to firm market value, where firm market value is measured as the sum of total debt plus the market value of equity. ${ }^{7}$ Following prior work (Ozkan, 2001; Fama and French, 2002; Leary and Roberts, 2005; Flannery and Rangan, 2006; Kayhan and Titman, 2007; Lockhart, 2010; Gungoraydinoglu and Öztekin, 2011; Oztekin and Flannery, 2012; Flannery et al., 2013; among others), we use a dynamic partial adjustment model. This model accounts for the potentially dynamic nature of firm capital structure. The model, thereby, allows us to test whether there is a target or optimal capital structure and if so, to uncover the speed at which firms move towards their targets. Moreover, this model allows us to further control for the potential impact of unobserved firmspecific, time-invariant, and institutional factors on each firm's target leverage. Specifically, an optimal capital structure model can be formalized as:

$$
D_{i j, t}^{*}=\alpha_{0}+\beta_{f} X_{i j, t}+\beta_{c} Y_{j, t}+\beta_{f c} X_{i j, t} Y_{j, t}+\delta_{i}+\varepsilon_{i t}
$$

where $D_{i j, t}^{*}$ is firm is optimal or target debt ratio at time $t$ in country $j, X_{i j, t}$ and $Y_{j, t}$ are, respectively, vectors of firm-level and country characteristics (institutional, macroeconomic) that determine the target debt ratio, $X_{i j, t} Y_{j, t}$ is the interaction between the firm-level and country-level determinants of capital structure, $\delta_{i}$ is an unabsorbed firm fixed effect. $\varepsilon_{i t}$ is a random error term assumed to be independently identical and normally distributed with zero mean and constant variance, $\varepsilon_{i t} \sim i i d N\left(0, \sigma^{2}\right)$.

In the ideal world with perfect markets (i.e., in the absence of asymmetric information and transaction or adjustment costs), firms fully and instantaneously adjust their capital structures to optimal leverage ratios in response to any variations in firm-level or country characteristics within each period of time. This implies that, at any point in time, a firm's actual leverage ratio should equal its optimum level, that is $D_{i, j, t}=D_{i j, t}^{*}$. However, in the presence of capital market imperfections, firms' capital structures do not completely and instantaneously adjust towards optimal leverage ratios. This implies that following a shock to the capital structure, a firm's actual leverage ratio will deviate from its optimal leverage, and then adjust partially towards the optimal ratio each period. Accordingly, the notion of partial adjustment can be formalized as follows:

$$
D_{i j, t}-D_{i j, t-1}=\gamma_{i j, t}\left(D_{i j, t}^{*}-D_{i j, t-1}\right)
$$

or

$$
D_{i j, t}=\left(1-\gamma_{i j, t}\right) D_{i j, t-1}+\gamma_{i j, t} D_{i j, t}^{*}
$$

where $\gamma_{i j, t}$ is the adjustment parameter representing the adjustment speed of a firm's actual leverage ratio $D_{i j, t}$ towards its optimal level, $D_{i j, t}^{*}$. This coefficient should strictly lie between 0 and 1 , with higher values indicating that the cost of deviating from the target is higher than the cost of adjustment and, hence, a high speed of adjustment towards the optimal leverage ratio.

\footnotetext{
${ }^{6}$ Since our data is collected from Worldscope database, our sample firms are mainly listed firms that tend to be among the largest firms in their respective counrties. We thus caution readers that our conclusions apply to large firms and may not necessarily be the same for other ones such as small and mid-sized firms.

${ }^{7}$ Examples of studies that used these two measures of firm leverage include Oztekin and Flannery, 2012; Antoniou et al., 2008 ; etc.
} 
Substituting Eq. (1) into the partial adjustment specification in Eq. (3) and re-arranging removes the unobservable optimal leverage $D_{i, j, t}^{*}$,and yields the following empirical model:

$$
D_{i j, t}=\vartheta_{0}+\theta_{0} D_{i j, t-1}+\Phi_{x_{f}} X_{i j, t}+\Phi_{y_{c}} Y_{j, t}+\Phi_{x_{f c}} X_{i j, t} Y_{j, t}+\mu_{i}+\omega_{i t}
$$

where $\vartheta_{0}=\alpha_{0} \gamma_{\mathrm{ij}, \mathrm{t}}, \theta_{0}=\left(1-\gamma_{\mathrm{ij}, \mathrm{t}}\right), \Phi_{\mathrm{x}_{\mathrm{f}}}=\beta_{\mathrm{f}} \gamma_{\mathrm{ij}, \mathrm{t}}, \Phi_{\mathrm{y}_{\mathrm{c}}}=\beta_{\mathrm{c}} \gamma_{\mathrm{ij}, \mathrm{t}}, \Phi_{\mathrm{x}_{\mathrm{fc}}}=\beta_{\mathrm{fc}} \gamma_{\mathrm{ij}, \mathrm{t}}, \mu_{\mathrm{i}}=\delta_{\mathrm{i}} \gamma_{\mathrm{ij}, \mathrm{t}}, \omega_{\mathrm{it}}=\varepsilon_{\mathrm{it}} \gamma_{\mathrm{ij}, \mathrm{t}}$

The dynamic panel model in Eq. (4) is estimated using the system GMM estimator of Arellano and Bover (1995) and Blundell and Bond (1998), which yields asymptotically efficient and consistent estimators by controlling for both unobserved individual heterogeneity (i.e., unobservable firm specific effects) and potential endogeneity problems (i.e., the potential correlation between the regression errors and the explanatory variables due to the existence of lagged dependent variables). This estimation combines the regression in differences with the regression in levels. The instruments for the regression in differences are the lagged levels of the corresponding variables. The instruments for the regression in levels are the lagged differences of the corresponding variables. ${ }^{8}$

As well known, the consistency of the GMM estimator depends on the assumption that the lagged values of the corresponding variables are valid instruments and that the first differenced regression residuals are free from second order serial correlation. To check for the validity of the instruments, we use Sargan test for overidentifying restrictions. We use Arellano-Bond AR (2) test to examine for the presence of second order serial correlation in the first differenced regression residuals.

Our regression equations also include industry-dummy variables to control for the potential impact of industry affiliation on corporate leverage. ${ }^{9}$ We use Campbell's (1996) industry classification to subdivide our sample firms into eleven industries. ${ }^{10}$

\section{Empirical results}

\subsection{Descriptive statistics}

Table 2 reports summary statistics for our two measures of corporate leverage by country as well as for the full sample. In a nutshell, it suggests that there is a large cross-country variation in corporate leverage, with the average BVD ranging from a minimum of $15.6 \%$ in Bahrain (median: $10.9 \%$ ) to a maximum of $47.5 \%$ in Oman (median: 46.3\%). Using market values - MVD -, Bahrain continues to be the country where firms are the least levered (Mean: 17.10\%; median: 10.6\%) and Oman continues to be the country with the most levered firms (Mean: 42.4\%; median: 41.2\%). Table 2 also suggests that there is a large within-country variation of corporate leverage with standard deviations typically above $20 \%$. The standard deviations of the book leverage ratios show that they vary most across Omani firms (26.9\%), while they vary least among Bahraini firms (14.2\%). The full sample statistics reveal that the average firm in the MENA region has a book leverage ratio (BVD) of $39 \%$, while the typical firm has a leverage ratio of $36.8 \%$ or less. Using the market leverage ratio shows that debt represents $33.4 \%$ of the market value of the average firm in the MENA region (median: 27.5\%). Table 3 presents mean values of our debt ratios over the sample period of 2003-2011. It shows that while average debt ratios have increased over time in some countries (e.g., Bahrain, Kuwait, Morocco, and Qatar) they have, however, decreased in some others (e.g., Egypt and Saudi Arabia).

Fig. 1 (Fig. 2) ranks MENA countries according to their mean values of BVD (MVD) from the lowest to the greatest. It shows that MENA countries fall into two groups according to their corporate leverage ratios. A group of relatively low corporate leverage represented by Bahrain, Jordan, Saudi Arabia, Qatar, and to some extent the UAE, and another group of relatively high corporate leverage made up of Kuwait, Tunisia, Morocco, Egypt, and Oman. Fig. 2, based on market values, confirms this observation, for almost all countries;

\footnotetext{
${ }^{8}$ In this paper, we perform a two-step Blundell and Bond system GMM using STATA 10 procedure 'xtdpdsys' with two- to five-period lags of the explanatory variables as instruments. In the Eq. (6), we also include dummy variables to control for unobserved country, industry and time-specific effects.

9 See, for instance, MacKay and Phillips (2005) and Miao (2005) for evidence on the importance of including industry dummies in analyses of corporate leverage.

${ }^{10}$ Indeed, Campbell (1996) identifies twelve industries including financial companies. Since we exclude the latter from our sample, we end up with eleven different industries.
} 
Table 2

Summary statistics of debt ratios.

\begin{tabular}{|c|c|c|c|c|c|c|c|c|c|c|c|c|c|c|c|c|c|}
\hline \multicolumn{18}{|c|}{ Panel A: Summary statistics of debt ratios by country } \\
\hline & \multirow[t]{2}{*}{ No. of firms } & \multirow[t]{2}{*}{ Observations } & \multicolumn{8}{|c|}{ Book value total debt ratio (BVD) } & \multicolumn{7}{|c|}{ Market value total debt ratio (MVD) } \\
\hline & & & Mean & Stdev & Min & $\begin{array}{l}\text { 25th } \\
\text { Percentile }\end{array}$ & Median & Max & $\begin{array}{l}\text { 75th } \\
\text { Percentile }\end{array}$ & Max & Mean & Stdev & Min & $\begin{array}{l}\text { 25th } \\
\text { Percentile }\end{array}$ & Median & Max & $\begin{array}{l}\text { 75th } \\
\text { Percentile }\end{array}$ \\
\hline UAE & 18 & 162 & 0.361 & 0.217 & 0.011 & 0.158 & 0.396 & 0.818 & 0.552 & 0.818 & 0.348 & 0.237 & 0.039 & 0.168 & 0.311 & 0.867 & 0.479 \\
\hline Bahrain & 18 & 162 & 0.156 & 0.142 & 0.034 & 0.054 & 0.109 & 0.655 & 0.323 & 0.655 & 0.171 & 0.189 & 0.036 & 0.071 & 0.106 & 0.820 & 0.181 \\
\hline Egypt & 93 & 837 & 0.472 & 0.255 & 0.090 & 0.287 & 0.472 & 0.921 & 0.612 & 0.921 & 0.408 & 0.256 & 0.028 & 0.189 & 0.368 & 0.855 & 0.583 \\
\hline Jordan & 79 & 711 & 0.315 & 0.216 & 0.020 & 0.148 & 0.280 & 0.977 & 0.438 & 0.977 & 0.288 & 0.239 & 0.007 & 0.109 & 0.222 & 0.905 & 0.389 \\
\hline Kuwait & 35 & 315 & 0.421 & 0.206 & 0.003 & 0.256 & 0.425 & 0.889 & 0.594 & 0.889 & 0.418 & 0.224 & 0.030 & 0.236 & 0.398 & 0.784 & 0.578 \\
\hline Morocco & 37 & 333 & 0.435 & 0.215 & 0.004 & 0.293 & 0.436 & 0.894 & 0.596 & 0.894 & 0.367 & 0.257 & 0.003 & 0.153 & 0.342 & 0.621 & 0.563 \\
\hline Oman & 62 & 558 & 0.475 & 0.269 & 0.033 & 0.260 & 0.463 & 0.947 & 0.675 & 0.947 & 0.424 & 0.258 & 0.013 & 0.202 & 0.412 & 0.897 & 0.685 \\
\hline Qatar & 16 & 144 & 0.323 & 0.251 & 0.049 & 0.120 & 0.222 & 0.903 & 0.456 & 0.903 & 0.278 & 0.213 & 0.036 & 0.116 & 0.218 & 0.812 & 0.471 \\
\hline Saudi Arabia & 55 & 495 & 0.318 & 0.201 & 0.002 & 0.154 & 0.265 & 0.847 & 0.471 & 0.847 & 0.202 & 0.191 & 0.002 & 0.063 & 0.127 & 0.791 & 0.290 \\
\hline Tunisia & 31 & 279 & 0.434 & 0.214 & 0.001 & 0.122 & 0.452 & 0.825 & 0.575 & 0.825 & 0.274 & 0.273 & 0.006 & 0.041 & 0.318 & 0.906 & 0.479 \\
\hline Full sample & 444 & 3717 & 0.390 & 0.244 & 0.001 & 0.197 & 0.368 & 0.977 & 0.566 & 0.977 & 0.334 & 0.247 & 0.002 & 0.126 & 0.275 & 0.906 & 0.505 \\
\hline
\end{tabular}


Table 3

Mean values of debt ratios by country over the sample period (2003-2011).

\begin{tabular}{lcccccccccc}
\hline \multirow{2}{*}{ UAE } & & 2003 & 2004 & 2005 & 2006 & 2007 & 2008 & 2009 & 2010 & 2011 \\
\multirow{5}{*}{ Bahrain } & BVD & 0.379 & 0.369 & 0.345 & 0.320 & 0.388 & 0.380 & 0.361 & 0.355 & 0.351 \\
& MVD & 0.348 & 0.348 & 0.238 & 0.196 & 0.334 & 0.383 & 0.411 & 0.422 & 0.461 \\
Egypt & BVD & 0.121 & 0.111 & 0.156 & 0.133 & 0.140 & 0.186 & 0.185 & 0.187 & 0.182 \\
& MVD & 0.164 & 0.174 & 0.169 & 0.110 & 0.142 & 0.175 & 0.170 & 0.211 & 0.220 \\
Jordan & BVD & 0.535 & 0.492 & 0.539 & 0.498 & 0.468 & 0.463 & 0.454 & 0.391 & 0.403 \\
& MVD & 0.550 & 0.475 & 0.528 & 0.353 & 0.355 & 0.313 & 0.376 & 0.369 & 0.349 \\
\multirow{3}{*}{ Kuwait } & BVD & 0.318 & 0.307 & 0.308 & 0.308 & 0.317 & 0.340 & 0.335 & 0.338 & 0.318 \\
& MVD & 0.240 & 0.248 & 0.250 & 0.247 & 0.265 & 0.285 & 0.298 & 0.325 & 0.335 \\
Morocco & BVD & 0.387 & 0.387 & 0.379 & 0.393 & 0.448 & 0.460 & 0.463 & 0.457 & 0.420 \\
& MVD & 0.306 & 0.306 & 0.328 & 0.305 & 0.422 & 0.425 & 0.541 & 0.560 & 0.560 \\
Oman & BVD & 0.324 & 0.361 & 0.391 & 0.458 & 0.487 & 0.487 & 0.490 & 0.494 & 0.481 \\
& MVD & 0.341 & 0.387 & 0.357 & 0.362 & 0.396 & 0.330 & 0.373 & 0.388 & 0.377 \\
Qatar & BVD & 0.484 & 0.484 & 0.464 & 0.454 & 0.464 & 0.479 & 0.455 & 0.464 & 0.484 \\
& MVD & 0.487 & 0.457 & 0.447 & 0.427 & 0.432 & 0.438 & 0.409 & 0.404 & 0.400 \\
Saudi Arabia & BVD & 0.217 & 0.237 & 0.287 & 0.332 & 0.385 & 0.360 & 0.393 & 0.368 & 0.358 \\
\multirow{2}{*}{ Tunisia } & MVD & 0.187 & 0.197 & 0.235 & 0.174 & 0.338 & 0.305 & 0.344 & 0.368 & 0.378 \\
& BVD & 0.368 & 0.362 & 0.350 & 0.314 & 0.326 & 0.305 & 0.327 & 0.300 & 0.320 \\
& MVD & 0.305 & 0.242 & 0.246 & 0.070 & 0.182 & 0.172 & 0.229 & 0.214 & 0.204 \\
& BVD & 0.388 & 0.367 & 0.375 & 0.369 & 0.390 & 0.382 & 0.394 & 0.407 & 0.430 \\
& MVD & 0.242 & 0.263 & 0.268 & 0.360 & 0.366 & 0.359 & 0.329 & 0.399 & 0.356 \\
\hline
\end{tabular}

Notes: This table presents the mean book and market value of total debt ratio of our sample firms in 10 MENA countries for the period of (2003-2011). Book value of total debt ratio (BVD) is measured by the ratio of total debt to total asset.Market value of total debt ratio (MVD) is measured by the ratio of total debt to the market value of equity plus the book value of debt.

the only exception is Tunisia, which moves to the low-corporate leverage side. Overall, our descriptive statistics show that leverage ratios in MENA countries are comparable to those observed in developing countries, reported in Booth et al. (2001) and Fan et al. (2012), but also to those reported by Antoniou et al. (2008) for the five most developed countries in the world - France, Germany, Japan, U.K., and U.S.

Table 4 reports mean values of the firm- and country-level variables used in the multivariate analysis of corporate leverage in MENA countries by country, as well as the full sample mean and standard deviation of each of these variables. We note that the UAE has the largest firms (SIZE: 5.651), followed closely by Qatar (SIZE: 5.612), while Jordan (SIZE: 4.446) has the smallest firms. A remarkable difference in tax regimes across MENA countries can be detected by looking at TAX. As regards the macroeconomic environment, Table 4 shows that there is large cross-country variation in GDP growth, with Qatar scoring the highest average growth rate over the sample period (GDPG: 15.1\%) and Bahrain having the lowest economic growth (GDPG: 2.5\%). The average annual inflation rate in MENA countries over the sample period was $4.7 \%$, with the lowest average inflation observed in Morocco (INF: 1.8\%) and the greatest inflation rate observed in Egypt (INF: 9.8\%). The quality of institutions also varies from one MENA country to another. Financial development varies widely across countries, with Oman having the least developed financial system (FD: -0.754) and Saudi Arabia having the most developed financial system (FD: -0.109). In terms of regulatory effectiveness, Governments of Bahrain (RE: 0.74), UAE (RE: 0.62), and Oman (RE: 061) are by far the most effective in setting up and implementing regulations that have an impact on the quality of the business environment, whereas the governments of Egypt and Morocco are the least effective ones in this matter. The rule of law index indicates that Qatar has the strictest rule of law (RL: 0.692) whereas Morocco has the weakest rule of law (RL: -0.138). Corruption is most rampant in Egypt (CORR: -0.57) and the least acute in the UAE (CORR: 1.03). Overall, even though MENA countries are often regarded as a uniform regional block with similar institutional characteristics, they, nevertheless, differ substantially in the quality of their institutions, which may have an impact on the way their firms finance their assets.

In Table 5, we report Pearson correlation coefficients between the different variables used in the analysis. We find that both measures of leverage are positively and significantly correlated with firm size and asset tangibility. Consistent with the predictions of the pecking order theory, both measures of leverage are negatively correlated with profitability. Furthermore, consistent with the predictions of the trade-off theory, BVD is positively correlated with TAX. In line with the pecking order theory, LIQ is negatively correlated with both measures of leverage. As predicted by the trade-off theory of capital structure, the market value of leverage (MVD) 


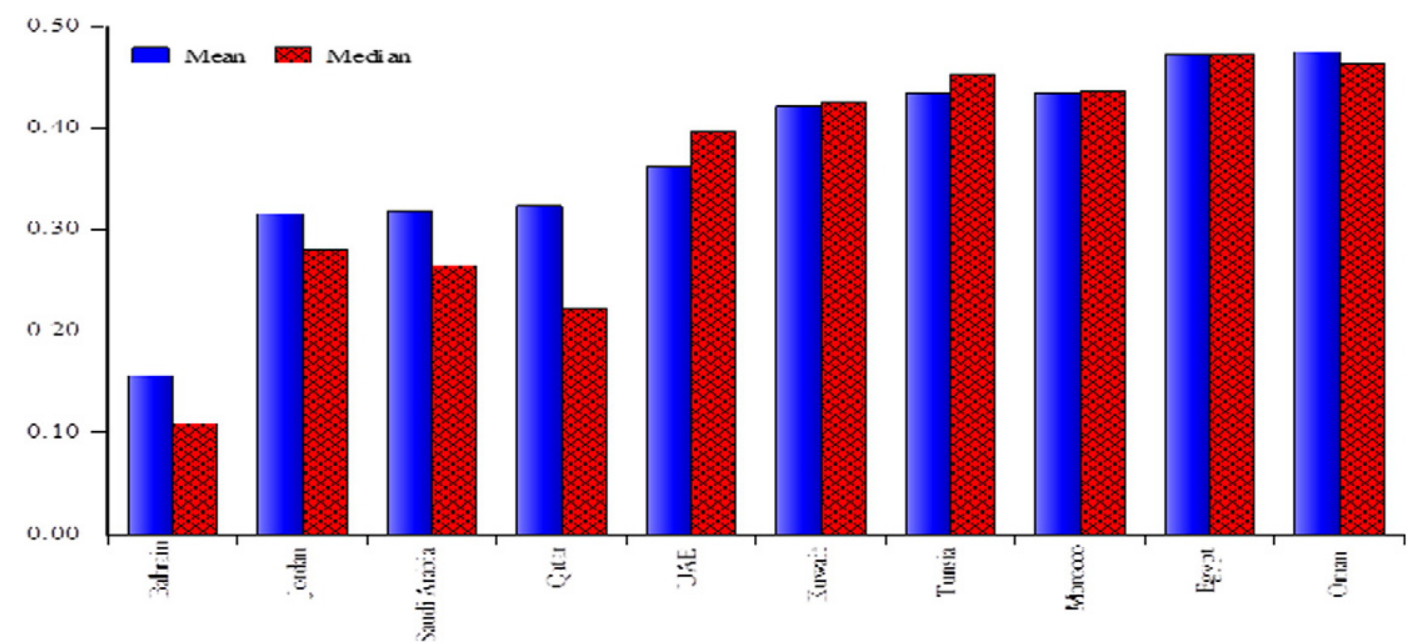

Fig. 1. Mean and median book value of total debt ratios. Notes: This figure presents the mean and median book value of total debt ratio of our sample firms in 10 MENA countries for the period of (2003-2011). Book value of total debt ratio is measured by the ratio of total debt to total asset. 


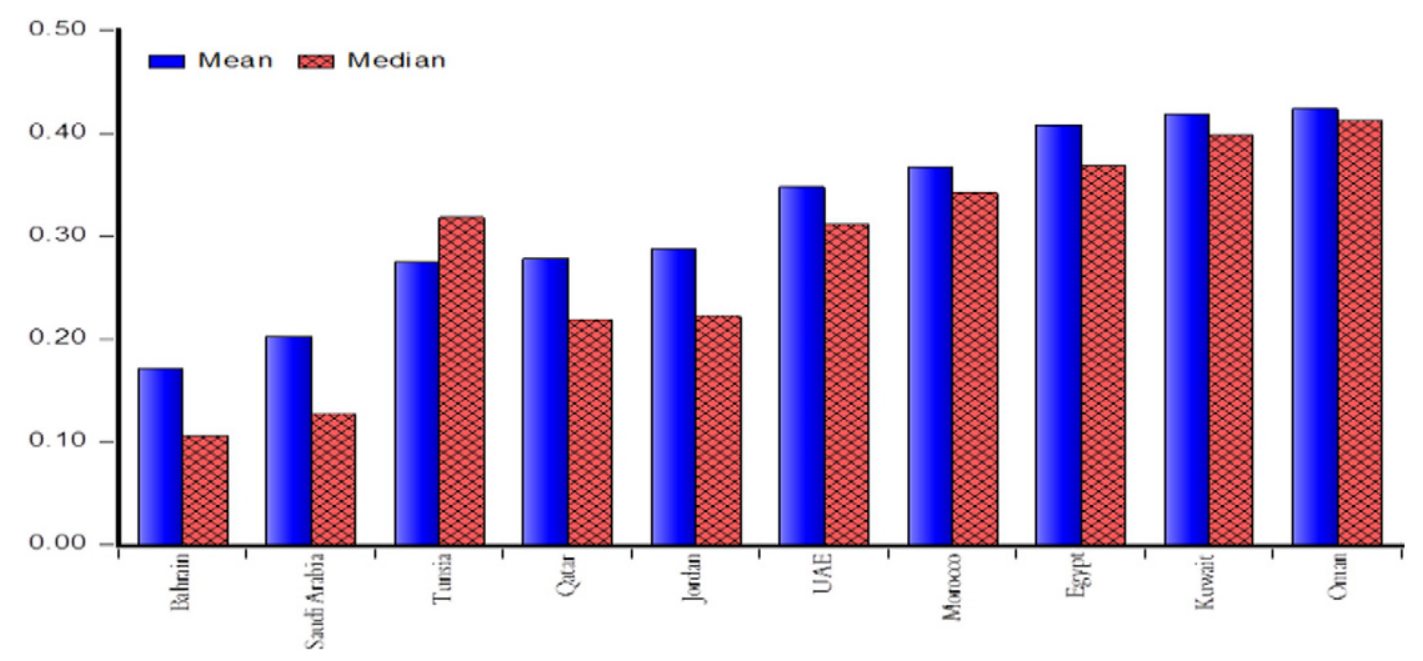

Fig. 2. Mean and median market value of total debt ratios. Notes: This figure presents the mean and median market value of total debt ratio of our sample firms in 10 MENA countries for the period of (2003-2011). Market value of total debt ratio is measured by the ratio of total debt to the market value of equity plus the book value of debt. 
Table 4

Summary statistics of explanatory variables and alternative variables used in the robustness tests.

\begin{tabular}{|c|c|c|c|c|c|c|c|c|c|c|c|c|c|c|c|}
\hline & \multicolumn{13}{|c|}{ Panel A: Main explanatory variables } & \multicolumn{2}{|c|}{$\begin{array}{l}\text { Panel B: } \\
\text { robustness tests' } \\
\text { variables }\end{array}$} \\
\hline & SIZE & TANG & PROF & TAX & Z-score & LIQ & GROWTH & GDPG & INF & FD & $\mathrm{RE}$ & RL & CORR & LTDR & TAX1 \\
\hline \multicolumn{16}{|l|}{$U A E$} \\
\hline Mean & 5.630 & 0.278 & 0.076 & 0.000 & 0.991 & 0.022 & 1.075 & 0.049 & 0.084 & -0.547 & 0.621 & 0.458 & 1.031 & 0.092 & 0.032 \\
\hline Stdev & 0.784 & 0.224 & 0.079 & 0.000 & 0.601 & 0.020 & 0.819 & 0.039 & 0.091 & 0.166 & 0.123 & 0.092 & 0.072 & 0.114 & 0.099 \\
\hline Median & 5.590 & 0.261 & 0.062 & 0.000 & 1.009 & 0.015 & 0.971 & 0.041 & 0.102 & -0.507 & 0.647 & 0.471 & 1.039 & 0.055 & 0.004 \\
\hline \multicolumn{16}{|l|}{ Bahrain } \\
\hline Mean & 4.893 & 0.253 & 0.103 & 0.000 & 1.548 & 0.042 & 1.177 & 0.002 & 0.023 & -0.492 & 0.741 & 0.630 & 0.330 & 0.036 & 0.065 \\
\hline Stdev & 0.466 & 0.231 & 0.074 & 0.000 & 0.697 & 0.045 & 2.277 & 0.026 & 0.010 & 0.055 & 0.041 & 0.163 & 0.117 & 0.047 & 0.174 \\
\hline Median & 4.862 & 0.154 & 0.099 & 0.000 & 1.401 & 0.023 & 0.931 & 0.009 & 0.022 & -0.503 & 0.737 & 0.580 & 0.248 & 0.027 & 0.001 \\
\hline \multicolumn{16}{|l|}{ Egypt } \\
\hline Mean & 4.935 & 0.340 & 0.101 & 0.296 & 1.311 & 0.017 & 1.569 & 0.053 & 0.099 & -0.485 & -0.346 & -0.054 & -0.570 & 0.092 & 0.054 \\
\hline Stdev & 0.735 & 0.232 & 0.113 & 5.066 & 1.111 & 0.033 & 7.591 & 0.014 & 0.042 & 0.094 & 0.156 & 0.106 & 0.095 & 0.134 & 0.146 \\
\hline Median & 4.900 & 0.336 & 0.092 & 0.118 & 1.263 & 0.011 & 0.835 & 0.047 & 0.093 & -0.535 & -0.414 & -0.051 & -0.532 & 0.024 & 0.007 \\
\hline \multicolumn{16}{|l|}{ Jordan } \\
\hline Mean & 4.407 & 0.382 & 0.034 & 0.089 & 0.892 & 0.024 & 3.590 & 0.063 & 0.049 & -0.027 & 0.284 & 0.389 & 0.305 & 0.072 & 0.047 \\
\hline Stdev & 0.611 & 0.246 & 0.113 & 1.237 & 1.045 & 0.049 & 35.151 & 0.024 & 0.043 & 0.170 & 0.063 & 0.085 & 0.128 & 0.108 & 0.107 \\
\hline Median & 4.330 & 0.356 & 0.035 & 0.044 & 0.899 & 0.011 & 0.745 & 0.079 & 0.050 & 0.022 & 0.319 & 0.413 & 0.304 & 0.049 & 0.009 \\
\hline \multicolumn{16}{|l|}{ Kuwait } \\
\hline Mean & 5.570 & 0.191 & 0.067 & 0.034 & 0.972 & 0.023 & 0.934 & 0.063 & 0.042 & -0.287 & 0.321 & 0.580 & 0.601 & 0.110 & 0.034 \\
\hline Stdev & 0.659 & 0.200 & 0.113 & 0.094 & 1.031 & 0.033 & 0.659 & 0.063 & 0.028 & 0.325 & 0.126 & 0.027 & 0.230 & 0.126 & 0.105 \\
\hline Median & 5.653 & 0.107 & 0.077 & 0.002 & 0.853 & 0.013 & 0.892 & 0.051 & 0.040 & -0.221 & 0.329 & 0.574 & 0.526 & 0.062 & 0.003 \\
\hline
\end{tabular}




\begin{tabular}{|c|c|c|c|c|c|c|c|c|c|c|c|c|c|c|c|}
\hline \multicolumn{16}{|l|}{ Morocco } \\
\hline Mean & 5.121 & 0.339 & 0.122 & 0.246 & 1.705 & 0.040 & 1.961 & 0.048 & 0.018 & -0.537 & -0.206 & -0.139 & -0.271 & 0.097 & 0.121 \\
\hline Stdev & 0.685 & 0.223 & 0.121 & 3.931 & 0.933 & 0.115 & 4.594 & 0.016 & 0.010 & 0.124 & 0.100 & 0.114 & 0.102 & 0.135 & 0.202 \\
\hline Median & 5.000 & 0.325 & 0.106 & 0.190 & 1.788 & 0.011 & 1.148 & 0.048 & 0.013 & -0.504 & -0.185 & -0.188 & -0.306 & 0.003 & 0.037 \\
\hline \multicolumn{16}{|l|}{ Oman } \\
\hline Mean & 4.417 & 0.481 & 0.051 & 0.249 & 1.024 & 0.019 & 1.027 & 0.044 & 0.039 & -0.754 & 0.611 & 0.560 & 0.367 & 0.144 & 0.066 \\
\hline Stdev & 0.557 & 0.266 & 0.114 & 2.526 & 1.558 & 0.030 & 0.850 & 0.038 & 0.035 & 0.095 & 0.067 & 0.115 & 0.112 & 0.177 & 0.118 \\
\hline median & 4.408 & 0.478 & 0.058 & 0.120 & 1.096 & 0.010 & 0.839 & 0.037 & 0.032 & -0.730 & 0.611 & 0.559 & 0.375 & 0.081 & 0.017 \\
\hline \multicolumn{16}{|l|}{ Qatar } \\
\hline Mean & 5.610 & 0.405 & 0.078 & 0.010 & 0.686 & 0.027 & 1.209 & 0.152 & 0.064 & -0.560 & 0.394 & 0.693 & 0.987 & 0.148 & 0.083 \\
\hline Stdev & 0.845 & 0.254 & 0.077 & 0.005 & 0.564 & 0.032 & 0.833 & 0.083 & 0.070 & 0.188 & 0.192 & 0.167 & 0.391 & 0.177 & 0.159 \\
\hline Median & 5.643 & 0.359 & 0.067 & 0.009 & 0.629 & 0.016 & 1.138 & 0.143 & 0.078 & -0.525 & 0.371 & 0.708 & 0.812 & 0.068 & 0.009 \\
\hline \multicolumn{16}{|c|}{ Saudi Arabia } \\
\hline Mean & 5.526 & 0.449 & 0.084 & 0.127 & 1.001 & 0.021 & 1.966 & 0.040 & 0.035 & -0.109 & 0.079 & 0.146 & -0.112 & 0.076 & 0.069 \\
\hline Stdev & 0.705 & 0.244 & 0.099 & 0.228 & 0.975 & 0.037 & 2.088 & 0.021 & 0.031 & 0.429 & 0.070 & 0.052 & 0.160 & 0.120 & 0.141 \\
\hline Median & 5.537 & 0.469 & 0.072 & 0.074 & 0.982 & 0.013 & 1.380 & 0.040 & 0.032 & -0.219 & 0.097 & 0.163 & -0.148 & 0.046 & 0.016 \\
\hline \multicolumn{16}{|l|}{ Tunisia } \\
\hline Mean & 4.736 & 0.304 & 0.075 & 0.034 & 1.431 & 0.017 & 1.354 & 0.048 & 0.036 & -0.537 & 0.018 & 0.137 & -0.011 & 0.107 & 0.061 \\
\hline Stdev & 0.472 & 0.169 & 0.065 & 1.038 & 0.524 & 0.015 & 1.749 & 0.011 & 0.009 & 0.030 & 0.079 & 0.084 & 0.177 & 0.114 & 0.090 \\
\hline Median & 4.646 & 0.305 & 0.069 & 0.029 & 1.462 & 0.012 & 0.846 & 0.055 & 0.036 & -0.554 & 0.004 & 0.159 & -0.088 & 0.069 & 0.027 \\
\hline \multicolumn{16}{|c|}{ Full sample } \\
\hline Mean & 4.923 & 0.370 & 0.073 & 0.257 & 1.119 & 0.023 & 1.895 & 0.052 & 0.055 & -0.371 & 0.156 & 0.269 & 0.075 & 0.097 & 0.059 \\
\hline Stdev & 0.804 & 0.251 & 0.111 & 2.856 & 1.125 & 0.046 & 16.567 & 0.037 & 0.048 & 0.335 & 0.370 & 0.280 & 0.479 & 0.137 & 0.133 \\
\hline Median & 4.847 & 0.349 & 0.066 & 0.125 & 1.126 & 0.012 & 0.913 & 0.047 & 0.045 & -0.434 & 0.165 & 0.295 & 0.187 & 0.341 & 0.010 \\
\hline
\end{tabular}

Notes: See Table 1 for detailed definition of each variable. The data set is a panel consists of 3717 firm-year observations representing 444 firms from 10 MENA countries over the period $2003-2011$. 
Table 5

Pearson Correlation coefficients.

\begin{tabular}{|c|c|c|c|c|c|c|c|c|c|c|c|c|c|c|c|}
\hline & BVD & MVD & SIZE & TANG & PROF & TAX & Z-score & LIQ & GROWTH & GDPG & INF & FD & $\mathrm{RE}$ & RL & CORR \\
\hline BVD & 1.000 & & & & & & & & & & & & & & \\
\hline MVD & $\begin{array}{c}0.793^{* * * *} \\
(0.000)\end{array}$ & 1.000 & & & & & & & & & & & & & \\
\hline SIZE & $\begin{array}{c}0.124^{* * *} \\
(0.000)\end{array}$ & $\begin{array}{c}0.109^{* * *} \\
(0.000)\end{array}$ & 1.000 & & & & & & & & & & & & \\
\hline TANG & $\begin{array}{c}0.386^{* * *} \\
(0.000)\end{array}$ & $\begin{array}{c}0.023 \\
(0.276)\end{array}$ & $\begin{array}{l}0.033^{* * *} \\
(0.041)\end{array}$ & 1.000 & & & & & & & & & & & \\
\hline PROF & $\begin{array}{c}-0.293^{* * *} \\
(0.000)\end{array}$ & $\begin{array}{c}-0.371^{* * *} \\
(0.000)\end{array}$ & $\begin{array}{c}0.201^{* * * *} \\
(0.000)\end{array}$ & $\begin{array}{c}-0.081^{* * *} \\
(0.000)\end{array}$ & 1.000 & & & & & & & & & & \\
\hline TAX & $\begin{array}{c}0.099^{* * * *} \\
(0.000)\end{array}$ & $\begin{array}{c}-0.259^{* * * *} \\
(0.007)\end{array}$ & $\begin{array}{l}-0.020 \\
(0.257)\end{array}$ & $\begin{array}{c}0.009 \\
(0.600)\end{array}$ & $\begin{array}{c}0.067^{* * *} \\
(0.000)\end{array}$ & 1.000 & & & & & & & & & \\
\hline Z-score & $\begin{array}{c}-0.322^{* * *} \\
(0.000)\end{array}$ & $\begin{array}{c}-0.293^{* * * *} \\
(0.000)\end{array}$ & $\begin{array}{c}0.081^{* * * *} \\
(0.000)\end{array}$ & $\begin{array}{c}-0.253^{* * *} \\
(0.000)\end{array}$ & $\begin{array}{c}0.754^{* * * *} \\
(0.000)\end{array}$ & $\begin{array}{c}0.018 \\
(0.326)\end{array}$ & 1.000 & & & & & & & & \\
\hline LIQ & $\begin{array}{c}-0.297^{* * *} \\
(0.000)\end{array}$ & $\begin{array}{c}-0.234^{* * *} \\
(0.000)\end{array}$ & $\begin{array}{c}-0.117^{* * *} \\
(0.000)\end{array}$ & $\begin{array}{c}-0.221^{* * * *} \\
(0.000)\end{array}$ & $\begin{array}{c}0.046^{* * * *} \\
(0.004)\end{array}$ & $\begin{array}{c}0.045^{* * *} \\
(0.009)\end{array}$ & $\begin{array}{c}0.091^{* * *} \\
(0.000)\end{array}$ & 1.000 & & & & & & & \\
\hline GROWTH & $\begin{array}{l}0.006 \\
0.698\end{array}$ & $\begin{array}{c}-0.202^{* * * *} \\
(0.000)\end{array}$ & $\begin{array}{c}-0.045^{* * * *} \\
(0.005)\end{array}$ & $\begin{array}{c}0.018 \\
(0.259)\end{array}$ & $\begin{array}{c}-0.052^{* * * *} \\
(0.001)\end{array}$ & $\begin{array}{l}-0.002 \\
(0.908)\end{array}$ & $\begin{array}{c}-0.077^{* * * *} \\
(0.000)\end{array}$ & $\begin{array}{c}-0.014 \\
(0.403)\end{array}$ & 1.000 & & & & & & \\
\hline RGDP & $\begin{array}{c}-0.233^{* *} \\
(0.041)\end{array}$ & $\begin{array}{l}-0.019 \\
(0.354)\end{array}$ & $\begin{array}{l}-0.018 \\
(0.279)\end{array}$ & $\begin{array}{l}-0.017 \\
(0.284)\end{array}$ & $\begin{array}{c}0.067^{* * *} \\
(0.000)\end{array}$ & $\begin{array}{l}-0.022 \\
(0.217)\end{array}$ & $\begin{array}{c}0.018 \\
(0.281)\end{array}$ & $\begin{array}{c}0.008 \\
(0.628)\end{array}$ & $\begin{array}{l}-0.010 \\
(0.536)\end{array}$ & 1.000 & & & & & \\
\hline INF & $\begin{array}{c}0.359^{* * * *} \\
(0.000)\end{array}$ & $\begin{array}{c}0.002 \\
(0.910)\end{array}$ & $\begin{array}{c}0.055^{* * * *} \\
(0.001)\end{array}$ & $\begin{array}{c}-0.051^{* * * *} \\
(0.001)\end{array}$ & $\begin{array}{l}0.029^{*} \\
(0.076)\end{array}$ & $\begin{array}{c}0.005 \\
(0.774)\end{array}$ & $\begin{array}{l}0.039^{* *} \\
(0.019)\end{array}$ & $\begin{array}{c}-0.056^{* * *} \\
(0.001)\end{array}$ & $\begin{array}{c}0.022 \\
(0.185)\end{array}$ & $\begin{array}{c}0.294^{* * * *} \\
(0.000)\end{array}$ & 1.000 & & & & \\
\hline FD & $\begin{array}{c}-0.202^{* * *} \\
(0.000)\end{array}$ & $\begin{array}{c}-0.238^{* * *} \\
(0.000)\end{array}$ & $\begin{array}{l}0.037^{* *} \\
(0.021)\end{array}$ & $\begin{array}{l}-0.010 \\
(0.528)\end{array}$ & $\begin{array}{c}0.025 \\
(0.131)\end{array}$ & $\begin{array}{c}-0.025 \\
(0.147)\end{array}$ & $\begin{array}{l}-0.026 \\
(0.132)\end{array}$ & $\begin{array}{c}0.028^{*} \\
(0.088)\end{array}$ & $\begin{array}{l}0.032^{* *} \\
(0.044)\end{array}$ & $\begin{array}{c}0.230^{* * * *} \\
(0.000)\end{array}$ & $\begin{array}{c}-0.067^{* * *} \\
(0.000)\end{array}$ & 1.000 & & & \\
\hline RE & $\begin{array}{c}-0.274^{* * *} \\
(0.000)\end{array}$ & $\begin{array}{c}-0.261^{* * * *} \\
(0.004)\end{array}$ & $\begin{array}{c}-0.081^{* * *} \\
(0.000)\end{array}$ & $\begin{array}{c}0.021 \\
(0.199)\end{array}$ & $\begin{array}{c}-0.122^{* * *} \\
(0.000)\end{array}$ & $\begin{array}{c}-0.068^{* * * *} \\
(0.000)\end{array}$ & $\begin{array}{c}-0.092^{* * *} \\
(0.000)\end{array}$ & $\begin{array}{l}0.037^{* * *} \\
(0.023)\end{array}$ & $\begin{array}{l}-0.012 \\
(0.478)\end{array}$ & $\begin{array}{c}0.050^{* * *} \\
(0.002)\end{array}$ & $\begin{array}{c}-0.212^{* * *} \\
(0.000)\end{array}$ & $\begin{array}{c}-0.086^{* * *} \\
(0.000)\end{array}$ & 1.000 & & \\
\hline RL & $\begin{array}{c}-0.357^{* * *} \\
(0.000)\end{array}$ & $\begin{array}{c}-0.136^{*} \\
(0.088)\end{array}$ & $\begin{array}{c}-0.094^{*} \\
(0.000)\end{array}$ & $\begin{array}{l}-0.018 \\
(0.258)\end{array}$ & $\begin{array}{c}-0.154^{* * *} \\
(0.000)\end{array}$ & $\begin{array}{c}-0.077^{* * *} \\
(0.000)\end{array}$ & $\begin{array}{c}-0.126^{* * * *} \\
(0.000)\end{array}$ & $\begin{array}{c}0.021 \\
(0.205)\end{array}$ & $\begin{array}{l}-0.008 \\
(0.611)\end{array}$ & $\begin{array}{c}0.098^{* * * *} \\
(0.000)\end{array}$ & $\begin{array}{c}-0.194^{* * * *} \\
(0.000)\end{array}$ & $\begin{array}{c}-0.058^{* * *} \\
(0.000)\end{array}$ & $\begin{array}{c}0.536^{* * * *} \\
(0.000)\end{array}$ & 1.000 & \\
\hline CORR & $\begin{array}{c}-0.383^{* * *} \\
(0.000)\end{array}$ & $\begin{array}{l}-0.023 \\
(0.280)\end{array}$ & $\begin{array}{c}0.013 \\
(0.424)\end{array}$ & $\begin{array}{c}-0.043^{* * * *} \\
(0.007)\end{array}$ & $\begin{array}{c}-0.121^{* * * *} \\
(0.000)\end{array}$ & $\begin{array}{c}-0.079^{* * * *} \\
(0.000)\end{array}$ & $\begin{array}{c}-0.112^{* * *} \\
(0.000)\end{array}$ & $\begin{array}{l}0.036^{* *} \\
(0.026)\end{array}$ & $\begin{array}{l}-0.011 \\
(0.508)\end{array}$ & $\begin{array}{c}0.174^{* * *} \\
(0.000)\end{array}$ & $\begin{array}{c}-0.243^{* * *} \\
(0.000)\end{array}$ & $\begin{array}{c}0.004 \\
(0.802)\end{array}$ & $\begin{array}{c}0.535^{* * *} \\
(0.000)\end{array}$ & $\begin{array}{l}0.662^{*} \\
(0.000\end{array}$ & 1.000 \\
\hline
\end{tabular}

Notes: This table presents correlation coefficients between variables. The data set is a panel consists of 3717 firm-year observations representing 444 firms from 10 MENA countries over the period 2003-2011. See Table 1 for the definition of variables. Numbers in parentheses indicate p- values. ${ }^{*},{ }^{* *}$ and ${ }^{* * *}$ indicate significance at the $10 \%, 5 \%$ and $1 \%$ levels, respectively. 
is negatively correlated with firm growth opportunities (GROWTH). We also notice that most of the correlation coefficients between firm-level variables are reasonably low, implying that multicollinearity is not a major concern for our analyses. We now turn to the multivariate analysis to check whether these univariate correlations continue to hold.

\subsection{Firm-level determinants of capital structure}

Table 6 reports the results of country-by-country regressions of corporate leverage on firm-specific factors. Results based on book leverage are reported in Panel A whereas those based on market leverage are reported in Panel B. We first notice that the one period lagged dependent variable - BVD or MVD - has a positive and significant effect on firm capital structure across all the MENA countries. ${ }^{11}$ The coefficient estimates on the lagged dependent variables vary between zero and one. Such a finding suggests that MENA firms have target capital structures towards which they adjust over time. The speed of adjustment with which firms move towards their targets, however, varies from one MENA country to another implying that adjustment costs are not uniform across the region. The fastest adjustment towards target book leverage is achieved by Bahraini firms, followed closely by Kuwaiti and UAE firms, whereas the slowest adjustment takes place in Jordan, Oman, Morocco and Qatar. The coefficient on lagged BVD in Bahrain implies that firms close almost 80\% (1-0.197) of the gap between observed and target leverage within one year. On the other extreme, Jordanian firms close slightly above half (1-0.455) of the gap within one year.

Using market leverage, Omani firms have the slowest adjustment speed towards target leverage; the coefficient estimate on lagged MVD equals 0.581, implying that firms close almost $42 \%$ of the gap within one year. Panel B also shows that Moroccan firms have the fastest adjustment towards target market leverage as they close $77.1 \%$ (1-0.229) of the gap within one year. Overall, our results suggest that capital structure decisions of firms located in MENA countries are dynamic, and that managers target specific leverage ratios measured in both book and market values. They also suggest that transaction costs vary substantially from one country to another, possibly because of differences in the quality of institutional environments. This, thereby, results in different speeds of adjustment towards target capital structures across these countries. Our results also suggest that speeds of adjustment in our sample countries are generally higher than those reported in the literature - 25\% in Antoniou et al. (2008), 28\% in Ebrahim et al. (2014), 34\% in Flannery and Rangan (2006), and up to $41 \%$ in Oztekin and Flannery (2012). A reasonable explanation of this finding lies with the type of firms included in our sample. These firms are the largest ones in their respective countries with good reputations in their national financial markets, which facilitate their access to capital at relatively low transaction costs. This is likely to lower their adjustment costs and speed up their adjustment towards their target leverages.

In step with the literature on other parts of the world (e.g., Rajan and Zingales, 1995; Booth et al., 2001; Antoniou et al., 2008; Frank and Goyal, 2009; Ebrahim et al., 2014), we find a positive and significant association between firm size and leverage in all countries and across the two measures of leverage, possibly reflecting the argument that large, more diversified, firms face lower default risk. The strong positive impact of size on leverage can, in fact, be reasonably attributed to the association of firm size with the (lower) probability of default given the existence of inefficient bankruptcy regimes across MENA countries. The nature of these regimes increases bankruptcy costs and makes access to debt capital by relatively small (riskier) firms difficult and particularly costly. The positive association between firm size and leverage across all our sample countries also reinforces the belief that information asymmetry between firm insiders and capital markets is a major problem in the MENA region, including for relatively large firms. In theory, larger firms suffer from less information asymmetries and should use less debt as they are more able to issue more informationally sensitive securities, such as stock. Yet, this does not square with our finding of a positive association between firm size and leverage, and suggests that MENA countries' firms do not gain much in transparency as they grow larger.

The estimated relation between asset tangibility (TANG) and corporate leverage is positive and significant in all countries and across the two measures of leverage. This is not a surprising result in a region where bankruptcy laws are not strongly protective of creditors and property rights' security is low. Credit may therefore

\footnotetext{
11 The only exception is the MVD regression for Qatar where the coefficient estimate on the dependent variable is positive but statistically insignificant.
} 
Table 6

Firm-level determinants of leverage: a country-by-country analysis.

\begin{tabular}{|c|c|c|c|c|c|c|c|c|c|c|}
\hline \multirow[t]{2}{*}{ Explanatory variables } & \multicolumn{10}{|l|}{ Country } \\
\hline & UAE & Bahrain & Egypt & Jordan & Kuwait & Morocco & Oman & Qatar & Saudi Arabia & Tunisia \\
\hline \multicolumn{11}{|c|}{ Panel A: Book value of total debt ratio (BVD) } \\
\hline $\mathrm{BVD}(\mathrm{t}-1)$ & $\begin{array}{l}0.197^{* * *} \\
(0.006)\end{array}$ & $\begin{array}{l}0.134^{* *} \\
(0.053)\end{array}$ & $\begin{array}{l}0.220^{* *} \\
(0.017)\end{array}$ & $\begin{array}{l}0.468^{* * *} \\
(0.009)\end{array}$ & $\begin{array}{l}0.192^{* *} \\
(0.025)\end{array}$ & $\begin{array}{l}0.412^{* * *} \\
(0.000)\end{array}$ & $\begin{array}{l}0.455^{* * *} \\
(0.000)\end{array}$ & $\begin{array}{l}0.400^{* * *} \\
(0.000)\end{array}$ & $\begin{array}{l}0.271^{* * *} \\
(0.009)\end{array}$ & $\begin{array}{l}0.326^{* * *} \\
(0.000)\end{array}$ \\
\hline SIZE & $\begin{array}{l}0.094^{* * * *} \\
(0.004)\end{array}$ & $\begin{array}{l}0.246^{* *} \\
(0.013)\end{array}$ & $\begin{array}{l}0.037^{* *} \\
(0.021)\end{array}$ & $\begin{array}{l}0.163^{* * *} \\
(0.005)\end{array}$ & $\begin{array}{l}0.120^{* *} \\
(0.012)\end{array}$ & $\begin{array}{l}0.376^{* * * *} \\
(0.000)\end{array}$ & $\begin{array}{l}0.341^{* * * *} \\
(0.000)\end{array}$ & $\begin{array}{l}0.180^{* *} \\
(0.020)\end{array}$ & $\begin{array}{l}0.184^{* * * *} \\
(0.009)\end{array}$ & $\begin{array}{l}0.268^{* * * *} \\
(0.000)\end{array}$ \\
\hline TANG & $\begin{array}{l}0.246^{* * * *} \\
(0.000)\end{array}$ & $\begin{array}{l}0.049^{* *} \\
(0.048)\end{array}$ & $\begin{array}{l}0.171^{* *} \\
(0.012)\end{array}$ & $\begin{array}{l}0.056^{* * *} \\
(0.004)\end{array}$ & $\begin{array}{l}0.303^{* *} \\
(0.019)\end{array}$ & $\begin{array}{l}0.317^{* * * *} \\
(0.000)\end{array}$ & $\begin{array}{l}0.122^{* *} \\
(0.020)\end{array}$ & $\begin{array}{l}0.115^{* * * *} \\
(0.004)\end{array}$ & $\begin{array}{l}0.307^{* *} \\
(0.023)\end{array}$ & $\begin{array}{l}0.302^{* * *} \\
(0.005)\end{array}$ \\
\hline PROF & $\begin{array}{l}-0.193^{* * *} \\
(0.000)\end{array}$ & $\begin{array}{l}-0.269 \\
(0.253)\end{array}$ & $\begin{array}{l}-0.280^{* * *} \\
(0.000)\end{array}$ & $\begin{array}{l}-0.302^{* *} \\
(0.171)\end{array}$ & $\begin{array}{l}-0.105 \\
(0.384)\end{array}$ & $\begin{array}{l}0.0251 \\
(0.097)\end{array}$ & $\begin{array}{l}-0.173^{* *} \\
(0.047)\end{array}$ & $\begin{array}{l}0.013 \\
(0.922)\end{array}$ & $\begin{array}{l}0.010 \\
(0.947)\end{array}$ & $\begin{array}{l}0.296 \\
(0.085)\end{array}$ \\
\hline TAX & - & - & $\begin{array}{l}0.004^{* * *} \\
(0.003)\end{array}$ & $\begin{array}{l}0.002^{* *} \\
(0.037)\end{array}$ & $\begin{array}{l}0.035 \\
(0.305)\end{array}$ & $\begin{array}{l}0.001^{* * *} \\
(0.046)\end{array}$ & $\begin{array}{l}0.015 \\
(0.714)\end{array}$ & $0.574(0.623)$ & $\begin{array}{l}0.009 \\
(0.731)\end{array}$ & $\begin{array}{l}0.011^{* * *} \\
(0.036)\end{array}$ \\
\hline Z-score & $\begin{array}{l}-0.072^{* *} \\
(0.026)\end{array}$ & $\begin{array}{l}-0.095^{* *} \\
(0.030)\end{array}$ & $\begin{array}{l}-0.293^{* * *} \\
(0.000)\end{array}$ & $\begin{array}{l}-0.110^{* * * *} \\
(0.000)\end{array}$ & $\begin{array}{l}-0.035^{* *} \\
(0.039)\end{array}$ & $\begin{array}{l}-0.070^{* * *} \\
(0.009)\end{array}$ & $\begin{array}{l}-0.106^{* * *} \\
(0.003)\end{array}$ & $\begin{array}{l}-0.271^{* *} \\
(0.017)\end{array}$ & $\begin{array}{l}-0.027^{* *} \\
(0.028)\end{array}$ & $\begin{array}{l}-0.154^{* * * *} \\
(0.000)\end{array}$ \\
\hline LIQ & $\begin{array}{l}-2.441^{* * *} \\
(0.000)\end{array}$ & $\begin{array}{l}-0.405 \\
(0.402)\end{array}$ & $\begin{array}{l}0.106 \\
(0.793)\end{array}$ & $\begin{array}{l}-0.509^{* *} \\
(0.017)\end{array}$ & $\begin{array}{l}-2.12^{* * *} \\
(0.012)\end{array}$ & $\begin{array}{l}-0.092^{* *} \\
(0.030)\end{array}$ & $\begin{array}{l}-0.677^{* * *} \\
(0.001)\end{array}$ & $-1.210(0.181)$ & $\begin{array}{l}-0.446^{* *} \\
(0.048)\end{array}$ & $\begin{array}{l}-0.496^{* *} \\
(0.045)\end{array}$ \\
\hline GROWTH & $\begin{array}{l}0.011^{* *} \\
(0.011)\end{array}$ & $\begin{array}{l}-0.0022 \\
(0.762)\end{array}$ & $\begin{array}{l}-0.007^{* *} \\
(0.036)\end{array}$ & $\begin{array}{l}0.0002 \\
(0.491)\end{array}$ & $\begin{array}{l}0.001 \\
(0.192)\end{array}$ & $\begin{array}{l}-0.001^{* * *} \\
(0.000)\end{array}$ & $\begin{array}{l}0.013 \\
(0.210)\end{array}$ & $\begin{array}{l}-0.076^{* *} \\
(0.029)\end{array}$ & $\begin{array}{l}0.000 \\
(0.953)\end{array}$ & $\begin{array}{l}-0.005 \\
(0.178)\end{array}$ \\
\hline Intercept & $\begin{array}{l}-0.075 \\
(0.729)\end{array}$ & $\begin{array}{l}-0.921^{* * *} \\
(0.050)\end{array}$ & $\begin{array}{l}0.907^{* * * *} \\
(0.006)\end{array}$ & $\begin{array}{l}-0.334^{* *} \\
(0.020)\end{array}$ & $\begin{array}{l}-0.203^{* *} \\
(0.025)\end{array}$ & $\begin{array}{l}-1.517^{* * *} \\
(0.010)\end{array}$ & $\begin{array}{l}0.585^{* * * *} \\
(0.006)\end{array}$ & $\begin{array}{l}0.712^{* *} \\
(0.044)\end{array}$ & $\begin{array}{l}-0.891^{* *} \\
(0.033)\end{array}$ & $\begin{array}{l}-0.655^{* * *} \\
(0.001)\end{array}$ \\
\hline Sargan test & $\begin{array}{l}11.867 \\
(0.920)\end{array}$ & $\begin{array}{l}6.006 \\
(0.998)\end{array}$ & $\begin{array}{l}20.721 \\
(0.413)\end{array}$ & $\begin{array}{l}23.888 \\
(0.247)\end{array}$ & $\begin{array}{l}20.849 \\
(0.406)\end{array}$ & $\begin{array}{l}19.716 \\
(0.475)\end{array}$ & $\begin{array}{l}17.685 \\
(0.409)\end{array}$ & $\begin{array}{l}12.027 \\
(0.525)\end{array}$ & $\begin{array}{l}14.804 \\
(0.321)\end{array}$ & $\begin{array}{l}5.714 \\
(0.999)\end{array}$ \\
\hline AR (2) test & $\begin{array}{l}1.073 \\
(0.283)\end{array}$ & $\begin{array}{l}-0.383 \\
(0.701)\end{array}$ & $\begin{array}{l}-0.763 \\
(0.445)\end{array}$ & $\begin{array}{l}-1.216 \\
(0.223)\end{array}$ & $\begin{array}{l}-1.894^{*} \\
(0.058)\end{array}$ & $\begin{array}{l}-1.549 \\
(0.121)\end{array}$ & $\begin{array}{l}-0.825 \\
(0.409)\end{array}$ & $\begin{array}{l}-1.985^{*} \\
(0.057)\end{array}$ & $\begin{array}{l}-0.649 \\
(0.516)\end{array}$ & $\begin{array}{l}-0.804 \\
(0.420)\end{array}$ \\
\hline
\end{tabular}


Panel B: Market value of total debt ratio (MVD)

\begin{tabular}{|c|c|c|c|c|c|c|c|c|c|c|}
\hline MVD (t-1) & $\begin{array}{l}0.253^{* * * *} \\
(0.000)\end{array}$ & $\begin{array}{l}0.352^{* *} \\
(0.036)\end{array}$ & $\begin{array}{l}0.292^{* * * *} \\
(0.000)\end{array}$ & $\begin{array}{l}0.475^{*} \\
(0.095)\end{array}$ & $\begin{array}{l}0.254^{* * * *} \\
(0.000)\end{array}$ & $\begin{array}{l}0.229^{* *} \\
(0.017)\end{array}$ & $\begin{array}{l}0.581^{* * * *} \\
(0.000)\end{array}$ & $\begin{array}{l}0.344 \\
(0.321)\end{array}$ & $\begin{array}{l}0.284^{* * * *} \\
(0.001)\end{array}$ & $\begin{array}{l}0.321^{* * * *} \\
(0.000)\end{array}$ \\
\hline SIZE & $0.269^{* * * *}$ & $0.475^{* *}$ & $0.145^{* *}$ & $0.378^{* * * *}$ & $0.256^{* * *}$ & $0.144^{* * *}$ & $0.248^{* *}$ & $0.238^{* *}$ & $0.415^{* * *}$ & $0.797^{* * * *}$ \\
\hline & $(0.004)$ & $(0.020)$ & $\begin{array}{l}(0.049) \\
0.164^{* *}\end{array}$ & $\begin{array}{l}(0.002) \\
0.265^{* *}\end{array}$ & $\begin{array}{l}(0.000) \\
0.322^{* * *}\end{array}$ & $\begin{array}{l}(0.000) \\
0.368^{* * *}\end{array}$ & $\begin{array}{l}(0.020) \\
0.210^{* *}\end{array}$ & $\begin{array}{l}(0.033) \\
0195^{* * *}\end{array}$ & $(0.000)$ & $\begin{array}{l}(0.005) \\
0.173^{* * *}\end{array}$ \\
\hline TANG & $\begin{array}{l}0.384^{* * * *} \\
(0.000)\end{array}$ & $\begin{array}{l}0.360^{* * * *} \\
(0.000)\end{array}$ & $\begin{array}{l}0.164^{* *} \\
(0.049)\end{array}$ & $\begin{array}{l}0.265^{* *} \\
(0.013)\end{array}$ & $\begin{array}{l}0.322^{* * * *} \\
(0.000)\end{array}$ & $\begin{array}{l}0.368^{* * * *} \\
(0.000)\end{array}$ & $\begin{array}{l}0.210^{* *} \\
(0.025)\end{array}$ & $\begin{array}{l}0.195^{* * * *} \\
(0.004)\end{array}$ & $\begin{array}{l}0.221^{* * * *} \\
(0.000)\end{array}$ & $\begin{array}{l}0.173^{* * * *} \\
(0.007)\end{array}$ \\
\hline PROF & $\begin{array}{l}-0.209 \\
(0.476)\end{array}$ & $\begin{array}{l}-0.270 \\
(0.109)\end{array}$ & $\begin{array}{l}-0.190 \\
(0.364)\end{array}$ & $\begin{array}{l}-0.151^{* *} \\
(0.029)\end{array}$ & $\begin{array}{l}-0.102 \\
(0.171)\end{array}$ & $\begin{array}{l}-0.418^{* * * *} \\
(0.000)\end{array}$ & $\begin{array}{l}-0.169^{* *} \\
(0.018)\end{array}$ & $\begin{array}{l}-1.683 \\
(0.137)\end{array}$ & $\begin{array}{l}-0.241^{* *} \\
(0.028)\end{array}$ & $\begin{array}{l}-0.076 \\
(0.392)\end{array}$ \\
\hline TAX & - & - & $\begin{array}{l}0.0023^{* * *} \\
(0.000)\end{array}$ & $\begin{array}{l}0.044^{* *} \\
(0.037)\end{array}$ & $\begin{array}{l}0.100^{* *} \\
(0.036)\end{array}$ & $\begin{array}{l}0.084^{* *} \\
(0.021)\end{array}$ & $\begin{array}{l}-0.118 \\
(0.256)\end{array}$ & $\begin{array}{l}0.470 \\
(0.131)\end{array}$ & $\begin{array}{l}0.003 \\
(0.842)\end{array}$ & $\begin{array}{l}0.053^{* * *} \\
(0.000)\end{array}$ \\
\hline Z-score (t) & $\begin{array}{l}-0.043 \\
(0.419)\end{array}$ & $\begin{array}{l}-0.098^{* *} \\
(0.013)\end{array}$ & $\begin{array}{l}-0.063^{*} \\
(0.067)\end{array}$ & $\begin{array}{l}-0.044^{* * * *} \\
(0.007)\end{array}$ & $\begin{array}{l}-0.041^{* * * *} \\
(0.000)\end{array}$ & $\begin{array}{l}-0.039^{* * * *} \\
(0.000)\end{array}$ & $\begin{array}{l}-0.040 \\
(0.115)\end{array}$ & $\begin{array}{l}0.051 \\
(0.716)\end{array}$ & $\begin{array}{l}-0.017^{* * * *} \\
(0.010)\end{array}$ & $\begin{array}{l}-0.105^{* *} \\
(0.039)\end{array}$ \\
\hline LIQ & $\begin{array}{l}-3.272^{* * *} \\
(0.000)\end{array}$ & $\begin{array}{l}-0.078 \\
(0.195)\end{array}$ & $\begin{array}{l}-4.412^{* * *} \\
(0.002)\end{array}$ & $\begin{array}{l}-0.650^{* *} \\
(0.011)\end{array}$ & $\begin{array}{l}-1.741^{* * *} \\
(0.010)\end{array}$ & $\begin{array}{l}-1.214 \\
(0.298)\end{array}$ & $\begin{array}{l}-0.741 \\
(0.215)\end{array}$ & $\begin{array}{l}-1.600^{* *} \\
(0.044)\end{array}$ & $\begin{array}{l}-0.285 \\
(0.327)\end{array}$ & $\begin{array}{l}-1.065^{*} \\
(0.065)\end{array}$ \\
\hline GROWTH & $\begin{array}{l}-0.099^{* * * *} \\
(0.000)\end{array}$ & $\begin{array}{l}0.016 \\
(0.461)\end{array}$ & $\begin{array}{l}-0.004^{* * * *} \\
(0.000)\end{array}$ & $\begin{array}{l}-0.000 \\
(0.144)\end{array}$ & $\begin{array}{l}-0.209^{* * * *} \\
(0.000)\end{array}$ & $\begin{array}{l}-0.176^{* * * *} \\
(0.000)\end{array}$ & $\begin{array}{l}-0.208^{* * * *} \\
(0.000)\end{array}$ & $\begin{array}{l}-0.069^{* *} \\
(0.046)\end{array}$ & $\begin{array}{l}-0.026^{* * * *} \\
(0.000)\end{array}$ & $\begin{array}{l}-0.095^{* * *} \\
(0.003)\end{array}$ \\
\hline Intercept & $\begin{array}{l}-0.974^{*} \\
(0.093)\end{array}$ & $\begin{array}{l}-1.073^{* *} \\
(0.047)\end{array}$ & $\begin{array}{l}-0.721^{* * *} \\
(0.001)\end{array}$ & $\begin{array}{l}-1.393^{* * * *} \\
(0.009)\end{array}$ & $\begin{array}{l}-0.901^{* * *} \\
(0.000)\end{array}$ & $\begin{array}{l}-0.259^{* *} \\
(0.031)\end{array}$ & $\begin{array}{l}0.489 \\
(0.144)\end{array}$ & $\begin{array}{l}-0.722 \\
(0.278)\end{array}$ & $\begin{array}{l}-2.152^{* * *} \\
(0.000)\end{array}$ & $\begin{array}{l}-3.208^{* *} \\
(0.036)\end{array}$ \\
\hline Sargan test & $\begin{array}{l}11.195 \\
(0.670)\end{array}$ & $\begin{array}{l}8.325 \\
(0.871)\end{array}$ & $\begin{array}{l}15.303 \\
(0.285)\end{array}$ & $\begin{array}{l}6.992 \\
(0.221)\end{array}$ & $\begin{array}{l}19.706 \\
(0.139)\end{array}$ & $\begin{array}{l}18.070 \\
(0.582)\end{array}$ & $\begin{array}{l}12.604 \\
(0.126)\end{array}$ & $\begin{array}{l}12.893 \\
(0.598)\end{array}$ & $\begin{array}{l}18.959 \\
(0.188)\end{array}$ & $\begin{array}{l}8.422 \\
(0.988)\end{array}$ \\
\hline AR (2) test & $\begin{array}{l}-0.135 \\
(0.892)\end{array}$ & $\begin{array}{l}-0.091 \\
(0.927)\end{array}$ & $\begin{array}{l}-0.884 \\
(0.376)\end{array}$ & $\begin{array}{l}-1.004 \\
(0.315)\end{array}$ & $\begin{array}{l}-0.711 \\
(0.476)\end{array}$ & $\begin{array}{l}-0.394 \\
(0.693)\end{array}$ & $\begin{array}{l}-0.059 \\
(0.952)\end{array}$ & $\begin{array}{l}-1.594 \\
(0.110)\end{array}$ & $\begin{array}{l}-1.422 \\
(0.154)\end{array}$ & $\begin{array}{l}-0.232 \\
(0.816)\end{array}$ \\
\hline
\end{tabular}

Notes: This table presents regression results of firm-specific determinants of debt ratio by country. See Table 1 and for the definition of the variables. Panel A reports the results of the book total debt ratio. Panel B reports the results of market total debt ratio. The data set is a panel consists of 3717 firm-year observations representing 444 firms from $10 \mathrm{MENA}$ countries over the period 2003-2011. The regressions are estimated using the two-step system GMM estimator of Arellano and Bover (1995) and Blundell and Bond (1998) with Windmeijer (2005) small-sample correction method. The t-2 lags of the variables used as instruments in the difference equation, and the same lags of differenced variables are used in the levels equation. Numbers in parentheses indicate p- values. All regressions include dummies to control for time, industry and firm fixed effects. Sargan test is a test for the validity of instruments and is asymptotically distributed as $\chi 2$ under the null of valid instruments. If p-value $>0.05$, we confirm the validity of instruments. AR (2) is a test for the second-order serial correlation and is asymptotically distributed as $\mathrm{N}(0,1)$ under the null of no serial correlation. If $\mathrm{p}$-value $>0.05$, we confirm of no serial correlation at order two in the first-differenced errors and the model is well specified. ${ }^{*}{ }^{* *}$ and ${ }^{* * *}$ indicate significance at the $10 \%, 5 \%$ and $1 \%$ levels, respectively. 
be conditional upon the availability of collateral, especially tangible assets; firms with more tangible assets can access debt financing at relatively better terms. This finding is consistent with Flannery and Rangan (2006) and Antoniou et al. (2008). As regards economic magnitude, Panel A shows that the coefficient estimate on TANG is largest in Morocco, suggesting that this country's firms depend the most on tangible assets to raise debt. One can reasonably link this finding to the quality of governance and institutions in Morocco. Among our sample countries, Morocco is only better than Egypt in terms of corruption and regulatory effectiveness, and is the worst in terms of rule of law. Sufficient tangible collateral may thus be the only guarantee that creditors can have to grant loans. Bahrain on the other hand has the weakest economic effect of TANG on firm leverage. It also has the highest score of regulatory effectiveness and the second best score in rule of law. Hence, the effect of tangible assets on corporate leverage is very likely reflecting the quality of countries' institutions.

The coefficient estimate on PROF is negative and significant in six out of the ten sample countries if we take the book and market leverage regressions together. In line with the pecking order theory, firm leverage in the UAE, Egypt, Jordan, Morocco, Oman, and Saudi Arabia reflects historical profitability. This result is consistent with the findings of several studies using international samples (Booth et al., 2001; Antoniou et al., 2008; De Jong et al., 2008; Fan et al., 2012, among others). The magnitude of the coefficient estimate on PROF in the book leverage (market leverage) regressions suggests that the strongest negative effect of profitability on corporate leverage is observed in Jordan (Morocco), possibly reflecting the severity of information asymmetries in these two countries; this may drive managers to rely primarily on internally generated funds to finance their investments.

In both Panels $\mathrm{A}$ and $\mathrm{B}$, we estimate a positive and significant relation between the corporate tax rate and leverage in non-GCC countries, which are Egypt, Jordan, Morocco, and Tunisia. Consistent with the trade-off model, in each of these countries, more tax payments lead firms to borrow more, most likely to benefit from the interest-tax shield. Yet, the economic magnitude of this advantage is very small; in Tunisia, where the coefficient estimate on TAX is the greatest, a 10 percent increase in the tax rate results in only $0.11 \%$ increase in corporate leverage. Apart from Kuwait in panel B, TAX has no impact on corporate leverage in any of the GCC countries, reflecting the lenient corporate tax regimes of these oil-rich countries. In the UAE and Bahrain, by law, corporations pay no taxes at all, while in Kuwait, listed companies are subject to a $2.5 \%$ income tax. In Saudi Arabia, the corporate income tax rate of $20 \%$ is applicable only to non-Saudi shareholders, while a religious tax (Zakat) at 2.5\% is levied on Saudi and GCC nationals or companies owned by them. In Qatar, the corporate tax rate is $10 \%$, but is generally applicable to only foreign investors; wholly owned Qatari/GCC entities are exempt from corporate taxation. Oman imposes corporate income at a rate of $12 \%$, irrespective of the form of the company or the nationality. In both panels $\mathrm{A}$ and $\mathrm{B}$, we find that firms with low probabilities of financial distress (high Z-score) use relatively less debt. This result is similar to Graham's (2000) findings for U.S firms.

Panel A and Panel B together reveal that growth opportunities (GROWTH) are negatively and significantly related to leverage in all countries, except in Bahrain and Jordan. This is consistent with the agency view of capital structure according to which high growth firms can reduce their agency costs by using less debt (Jensen and Meckling, 1976). Antoniou et al. (2008) report similar results for their sample of five developed countries. A cross-country comparison reveals that there is a remarkable difference in the economic magnitude of the impact of GROWTH on leverage. Specifically, Panel B suggests that raising debt by firms with high growth opportunities is relatively much costlier in Kuwait and Oman. In sum, the country by country estimations reveal that the growth opportunities-corporate leverage relation in the MENA region is consistent with other regions. It also suggests that the institutional environment may play a role in the extent to which growth opportunities limit firms' use of debt, as the magnitude of this inverse relation varies across countries.

Taken together, panels A and B show that we estimate a negative and significant relation between firm liquidity (LIQ) and leverage in nine out of the ten sample countries, with Bahrain being the only country where LIQ is not significantly associated with neither book nor market leverage. This inverse relation between a firm's asset liquidity and leverage is consistent with Myers and Rajan (1998) and Morellec (2001) theoretical view that lower asset liquidity increases managers' costs of expropriating value from creditors, and thus, reduces the cost of debt, thereby inducing firms to increase their financial leverage. This view is of particular relevance in MENA countries where firms suffer from the lack of good corporate governance practices and the risk of expropriation is typically high. Hence, creditors may be reluctant to extend credit to firms with important liquid assets that can be prone to easy expropriation. The alternative interpretation of this finding is that 
because MENA collateral regimes are underdeveloped, and do not allow for the use of liquid assets, such as receivables and marketable securities, as loan collateral, firms with more of these assets are less able to raise debt, ceteris paribus.

\subsection{Institutions and corporate leverage in the MENA region}

To estimate the impact of institutional factors on financial leverage, we pool all observations from the ten MENA countries and regress book leverage and market leverage on the set of firm- and country-level variables described above. We include our four institutional factors in separate regressions to avoid problems of multicollinearity. We first report, in columns (1) and (7) of Table 7, the pooled regressions of book leverage and market leverage on firm-level factors. Overall, the results suggest that, in the MENA region taken as a whole, corporate leverage is positively related to firm size and tangibility and negatively related to profitability, default risk, tax payments, liquid assets and growth opportunities. Further, the coefficient estimates on most of the firm-level variables are economically meaningful. For instance, the coefficient estimate on SIZE in column (1) indicates that, on average, a one-unit increase in firm size results in a 5.5\% increase in corporate leverage in the MENA region. Likewise, based on column (1), the estimated coefficient on TANG in column (1) suggests that a one-unit increase in tangible assets leads to an increase in the leverage ratio of 16.1 percentage points whereas the coefficient estimate on PROF implies that a one-unit increase in profitability leads to a decrease in the debt ratio by 20 percentage points. Moreover, a one-unit increase in the likelihood of default measured by the Z-score lowers book leverage by $10.7 \%$ while a one-unit increase in LIQ reduces the debt ratio by 47.5 percentage points, ceteris paribus.

In columns (2) and (8), we further control for GDP growth rate and inflation. We find that firms located in countries with greater economic growth and higher inflation rates operate with more financial leverage. As regards economic magnitude, the estimated coefficients on GDP growth in columns (2) and (8) indicate that a one-unit increase in GDP growth is associated with an increase in the book (market) leverage of nearly 39.4 (14.7) percentage points. Similarly, columns (2) and (8) indicate that a one-unit increase in inflation is associated with an increase in the book (market) leverage of nearly 5.7 (28.5) percentage points, ceteris paribus. We next estimate the impact of financial development on leverage by including FD as an additional explanatory variable. Both columns (3) and (9) suggest that firms located in countries with relatively more developed financial systems use more debt; the coefficient estimate on FD is positive and significant in both book and market leverage regressions. The impact of FD is also economically significant as a one-unit increase in the FD index is associated with an increase in the book (market) leverage of nearly three (two) percentage points, ceteris paribus. This result suggests that debt capital supply is an important factor that determines the degree of firm financial leverage in the MENA region. Financial leverage is not a merely firm-level decision, but also depends on the extent to which a country's financial system is able to satisfy firms' demand for debt capital. Our finding that financial development is a significant determinant of firm financial leverage over-and-above firm-level factors is all the more reasonable in the MENA region where financial systems tend to be weak; any improvement in a country's financial system is expected to boost firms' access to debt capital.

In columns (4) and (10), we estimate the impact of another measure of the institutional environment on corporate leverage in the MENA region, namely regulatory effectiveness. We find that the coefficient estimate on RE loads positive and significant, suggesting that corporate leverage increases with the improvement in authorities' regulatory effectiveness and quality. The estimated coefficients on RE in columns (4) and (10) indicate that a one-unit increase in RE is associated with an increase in the book (market) leverage of nearly five (seven) percentage points. We next estimate the impact of the rule of law on corporate leverage. While the coefficient on RL in column (5) is positive but insignificant, it is, however, positive and significant at the $1 \%$ level in column (11) indicating that market leverage increases in the strength of the rule of law. In other words, firms borrow more in countries where agents abide by the rule of law, property rights are better protected and contracts enforced more effectively. Economically, the coefficient estimate on RL in column (11) indicates that a-one unit increase in RL raises market leverage by $8.7 \%$. Corruption control also appears to play a significant role in determining corporate leverage in the MENA region; CORR appears with a negative and significant coefficient estimate in both columns (6) and (12), implying that more severe corruption (lower CORR) leads to greater borrowing by firms. This is consistent with the view that corruption can be an effective means for firms to get around regulations and stringent bank requirements related to collateral 
Table 7

Institutions and firm leverage in the MENA region.

\begin{tabular}{|c|c|c|c|c|c|c|c|c|c|c|c|c|}
\hline & $(1)$ & $(2)$ & (3) & $(4)$ & (5) & $(6)$ & (7) & $(8)$ & (9) & $(10)$ & $(11)$ & $(12)$ \\
\hline & \multicolumn{6}{|c|}{ Panel A: Book value of total debt ratio (BVD) } & \multicolumn{6}{|c|}{ Panel B: Market value of total debt ratio (MVD) } \\
\hline Debt (t-1) & $\begin{array}{l}0.557^{* * *} \\
(0.000)\end{array}$ & $\begin{array}{l}0.571^{* * *} \\
(0.000)\end{array}$ & $\begin{array}{l}0.569^{* * * *} \\
(0.000)\end{array}$ & $\begin{array}{l}0.571^{* * * *} \\
(0.000)\end{array}$ & $\begin{array}{l}0.559^{* * *} \\
(0.000)\end{array}$ & $\begin{array}{l}0.572^{* * * *} \\
(0.000)\end{array}$ & $\begin{array}{l}0.315^{* * * *} \\
(0.000)\end{array}$ & $\begin{array}{l}0.326^{* * *} \\
(0.000)\end{array}$ & $\begin{array}{l}0.345^{* * *} \\
(0.000)\end{array}$ & $\begin{array}{l}0.330^{* * * *} \\
(0.000)\end{array}$ & $\begin{array}{l}0.305^{* * *} \\
(0.000)\end{array}$ & $\begin{array}{l}0.289^{* * *} \\
(0.000)\end{array}$ \\
\hline SIZE & $\begin{array}{l}0.055^{* * * *} \\
(0.000)\end{array}$ & $\begin{array}{l}0.067^{* * * *} \\
(0.000)\end{array}$ & $\begin{array}{l}0.068^{* * * *} \\
(0.000)\end{array}$ & $\begin{array}{l}0.077^{* * *} \\
(0.000)\end{array}$ & $\begin{array}{l}0.068^{* * * *} \\
(0.000)\end{array}$ & $\begin{array}{l}0.067^{* * * *} \\
(0.000)\end{array}$ & $\begin{array}{l}0.051^{* * * *} \\
(0.000)\end{array}$ & $\begin{array}{l}0.058^{* * * *} \\
(0.000)\end{array}$ & $\begin{array}{l}0.058^{* * * *} \\
(0.000)\end{array}$ & $\begin{array}{l}0.056^{* * * *} \\
(0.000)\end{array}$ & $\begin{array}{l}0.065^{* * * *} \\
(0.002)\end{array}$ & $\begin{array}{l}0.056^{* * *} \\
(0.000)\end{array}$ \\
\hline TANG & $\begin{array}{l}0.161^{* *} \\
(0.035)\end{array}$ & $\begin{array}{l}0.172^{*} \\
(0.083)\end{array}$ & $\begin{array}{l}0.173^{*} \\
(0.077)\end{array}$ & $\begin{array}{l}0.200^{* * *} \\
(0.022)\end{array}$ & $\begin{array}{l}0.165^{* *} \\
(0.047)\end{array}$ & $\begin{array}{l}0.177^{* * *} \\
(0.038)\end{array}$ & $\begin{array}{l}0.109^{*} \\
(0.081)\end{array}$ & $\begin{array}{l}0.159^{*} \\
(0.057)\end{array}$ & $\begin{array}{l}0.160^{* *} \\
(0.050)\end{array}$ & $\begin{array}{l}0.374^{* * *} \\
(0.042)\end{array}$ & $\begin{array}{l}0.441^{* * *} \\
(0.045)\end{array}$ & $\begin{array}{l}0.563^{* *} \\
(0.035)\end{array}$ \\
\hline PROF & $\begin{array}{l}-0.200^{\text {*** }} \\
(0.000)\end{array}$ & $\begin{array}{l}-0.200^{\text {**** }} \\
(0.000)\end{array}$ & $\begin{array}{l}-0.196^{* * * *} \\
(0.000)\end{array}$ & $\begin{array}{l}-0.196^{\text {**** }} \\
(0.000)\end{array}$ & $\begin{array}{l}-0.202^{* * *} \\
(0.000)\end{array}$ & $\begin{array}{l}-0.200^{\text {*** }} \\
(0.000)\end{array}$ & $\begin{array}{l}-0.269^{* * *} \\
(0.000)\end{array}$ & $\begin{array}{l}-0.213^{* *} \\
(0.014)\end{array}$ & $\begin{array}{l}-0.204^{* *} \\
(0.020)\end{array}$ & $\begin{array}{l}-0.224^{* *} \\
(0.014)\end{array}$ & $\begin{array}{l}-0.229^{* * *} \\
(0.007)\end{array}$ & $\begin{array}{l}-0.247^{\text {**** }} \\
(0.004)\end{array}$ \\
\hline TAX & $\begin{array}{l}0.001 \\
(0.462)\end{array}$ & $\begin{array}{l}0.000 \\
(0.584)\end{array}$ & $\begin{array}{l}0.000 \\
(0.596)\end{array}$ & $\begin{array}{l}0.000 \\
(0.586)\end{array}$ & $\begin{array}{l}0.000 \\
(0.601)\end{array}$ & $\begin{array}{l}0.000 \\
(0.584)\end{array}$ & $\begin{array}{l}0.004^{* * * *} \\
(0.000)\end{array}$ & $\begin{array}{l}0.004^{* * * *} \\
(0.000)\end{array}$ & $\begin{array}{l}0.005^{* * * *} \\
(0.000)\end{array}$ & $\begin{array}{l}0.004^{* * * *} \\
(0.001)\end{array}$ & $\begin{array}{l}0.004^{* * * *} \\
(0.000)\end{array}$ & $\begin{array}{l}0.004^{* * *} \\
(0.001)\end{array}$ \\
\hline Z-score & $\begin{array}{l}-0.107^{\text {**** }} \\
(0.000)\end{array}$ & $\begin{array}{l}-0.108^{* * *} \\
(0.000)\end{array}$ & $\begin{array}{l}-0.108^{* * * *} \\
(0.000)\end{array}$ & $\begin{array}{l}-0.107^{* * *} \\
(0.000)\end{array}$ & $\begin{array}{l}-0.109^{* * *} \\
(0.000)\end{array}$ & $\begin{array}{l}-0.108^{* * *} \\
(0.000)\end{array}$ & $\begin{array}{l}-0.089^{* * *} \\
(0.000)\end{array}$ & $\begin{array}{l}-0.081^{* * *} \\
(0.000)\end{array}$ & $\begin{array}{l}-0.080^{* * * *} \\
(0.000)\end{array}$ & $\begin{array}{l}-0.083^{* * *} \\
(0.000)\end{array}$ & $\begin{array}{l}-0.082^{* * * *} \\
(0.000)\end{array}$ & $\begin{array}{l}-0.085^{* * *} \\
(0.000)\end{array}$ \\
\hline LIQ & $\begin{array}{l}-0.475^{\text {**** }} \\
(0.000)\end{array}$ & $\begin{array}{l}-0.460^{* * *} \\
(0.000)\end{array}$ & $\begin{array}{l}-0.459^{* * *} \\
(0.000)\end{array}$ & $\begin{array}{l}-0.470^{\text {**** }} \\
(0.000)\end{array}$ & $\begin{array}{l}-0.458^{* * *} \\
(0.000)\end{array}$ & $\begin{array}{l}-0.460^{* * *} \\
(0.000)\end{array}$ & $\begin{array}{l}-0.854^{* * *} \\
(0.000)\end{array}$ & $\begin{array}{l}-0.901^{* * *} \\
(0.000)\end{array}$ & $\begin{array}{l}-0.903^{* * * *} \\
(0.000)\end{array}$ & $\begin{array}{l}-0.912^{* * *} \\
(0.000)\end{array}$ & $\begin{array}{l}-0.896^{* * * *} \\
(0.001)\end{array}$ & $\begin{array}{l}-0.892^{* * *} \\
(0.002)\end{array}$ \\
\hline Growth & $\begin{array}{l}0.000 \\
(0.214)\end{array}$ & $\begin{array}{l}0.000 \\
(0.231)\end{array}$ & $\begin{array}{l}0.000 \\
(0.255)\end{array}$ & $\begin{array}{l}0.000 \\
(0.237)\end{array}$ & $\begin{array}{l}0.000 \\
(0.221)\end{array}$ & $\begin{array}{l}0.000 \\
(0.231)\end{array}$ & $\begin{array}{l}-0.001^{* * *} \\
(0.000)\end{array}$ & $\begin{array}{l}-0.001^{* * *} \\
(0.000)\end{array}$ & $\begin{array}{l}-0.001^{* * *} \\
(0.000)\end{array}$ & $\begin{array}{l}-0.001^{* * *} \\
(0.000)\end{array}$ & $\begin{array}{l}-0.001^{* * *} \\
(0.001)\end{array}$ & $\begin{array}{l}-0.001^{\text {*** }} \\
(0.000)\end{array}$ \\
\hline RGDP & & $\begin{array}{l}0.394^{* * * *} \\
(0.000)\end{array}$ & $\begin{array}{l}0.360^{* * * *} \\
(0.000)\end{array}$ & $\begin{array}{l}0.432^{* * *} \\
(0.000)\end{array}$ & $\begin{array}{l}0.402^{* * * *} \\
(0.000)\end{array}$ & $\begin{array}{l}0.394^{* * * *} \\
(0.000)\end{array}$ & & $\begin{array}{l}0.147^{* *} \\
(0.020)\end{array}$ & $\begin{array}{l}0.212^{*} \\
(0.082)\end{array}$ & $\begin{array}{l}0.191 \\
(0.101)\end{array}$ & $\begin{array}{l}0.134^{*} \\
(0.091)\end{array}$ & $\begin{array}{l}0.136 \\
(0.228)\end{array}$ \\
\hline INF & & $\begin{array}{l}0.057^{* *} \\
(0.027)\end{array}$ & $\begin{array}{l}0.065^{*} \\
(0.055)\end{array}$ & $\begin{array}{l}0.072^{* *} \\
(0.023)\end{array}$ & $\begin{array}{l}0.076^{* *} \\
(0.012)\end{array}$ & $\begin{array}{l}0.057^{* *} \\
(0.018)\end{array}$ & & $\begin{array}{l}0.285^{* * * *} \\
(0.118)\end{array}$ & $\begin{array}{l}0.272^{* * *} \\
(0.001)\end{array}$ & $\begin{array}{l}0.302^{* * * *} \\
(0.000)\end{array}$ & $\begin{array}{l}0.335^{* * * *} \\
(0.000)\end{array}$ & $\begin{array}{l}0.304^{* * * *} \\
(0.000)\end{array}$ \\
\hline FD & & & $\begin{array}{l}0.028^{* *} \\
(0.038)\end{array}$ & & & & & & $\begin{array}{l}0.017^{* *} \\
(0.035)\end{array}$ & & & \\
\hline $\mathrm{RE}$ & & & & $\begin{array}{l}0.055^{* *} \\
(0.037)\end{array}$ & & & & & & $\begin{array}{l}0.071^{* *} \\
(0.037)\end{array}$ & & \\
\hline RL & & & & & $\begin{array}{l}0.031 \\
(0.169)\end{array}$ & & & & & & $\begin{array}{l}0.087^{* * * *} \\
(0.006)\end{array}$ & \\
\hline CORR & & & & & & $\begin{array}{l}-0.007^{*} \\
(0.082)\end{array}$ & & & & & & $\begin{array}{l}-0.077^{* * *} \\
(0.000)\end{array}$ \\
\hline Intercept & $\begin{array}{l}0.012 \\
(0.838)\end{array}$ & $\begin{array}{l}0.074 \\
(0.274)\end{array}$ & $\begin{array}{l}0.073 \\
(0.282)\end{array}$ & $\begin{array}{l}0.122^{*} \\
(0.089)\end{array}$ & $\begin{array}{l}0.083 \\
(0.220)\end{array}$ & $\begin{array}{l}0.074^{*} \\
(0.274)\end{array}$ & $\begin{array}{l}0.065 \\
(0.288)\end{array}$ & $\begin{array}{l}0.053 \\
(0.388)\end{array}$ & $\begin{array}{l}0.055 \\
(0.375)\end{array}$ & $\begin{array}{l}0.058 \\
(0.348)\end{array}$ & $\begin{array}{l}0.013 \\
(0.827)\end{array}$ & $\begin{array}{l}0.086 \\
(0.156)\end{array}$ \\
\hline Sargan test & $\begin{array}{l}23.809 \\
(0.168)\end{array}$ & $\begin{array}{l}19.376 \\
(0.115)\end{array}$ & $\begin{array}{l}20.089 \\
(0.128)\end{array}$ & $\begin{array}{l}19.893^{*} \\
(0.063)\end{array}$ & $\begin{array}{l}17.588^{*} \\
(0.091)\end{array}$ & $\begin{array}{l}19.561 \\
(0.120)\end{array}$ & $\begin{array}{l}78.235 \\
(0.137)\end{array}$ & $\begin{array}{l}76.266 \\
(0.151)\end{array}$ & $\begin{array}{l}55.114 \\
(0.233)\end{array}$ & $\begin{array}{l}72.095 \\
(0.185)\end{array}$ & $\begin{array}{l}57.285 \\
(0.214)\end{array}$ & $\begin{array}{l}75.465 \\
(0.149)\end{array}$ \\
\hline AR (2) test & $\begin{array}{l}0.575 \\
(0.564)\end{array}$ & $\begin{array}{l}0.4753 \\
(0.634)\end{array}$ & $\begin{array}{l}0.501 \\
(0.615)\end{array}$ & $\begin{array}{l}0.483 \\
(0.628)\end{array}$ & $\begin{array}{l}0.493 \\
(0.621)\end{array}$ & $\begin{array}{l}0.474 \\
(0.635)\end{array}$ & $\begin{array}{l}1.211 \\
(0.270)\end{array}$ & $\begin{array}{l}1.754^{*} \\
(0.079)\end{array}$ & $\begin{array}{l}1.455 \\
(0.145)\end{array}$ & $\begin{array}{l}1.638 \\
(0.101)\end{array}$ & $\begin{array}{l}1.650^{*} \\
(0.098)\end{array}$ & $\begin{array}{l}1.375 \\
(0.169)\end{array}$ \\
\hline
\end{tabular}

Notes: This table presents regression results of firm- country- and institutional specific determinants of debt ratio across countries. See Table 1 and for the definition of the variables. The data set is a panel consists of 3717 firm-year observations representing 444 firms from 10 MENA countries over the period 2003-2011. The regressions are estimated using the two-step system GMM estimator of Arellano and Bover (1995) and Blundell and Bond (1998) with Windmeijer (2005) small-sample correction method. The $t-2$ lags of the variables used as instruments in the difference equation, and the same lags of differenced variables are used in the levels equation. All models are estimated with a switched on clustering option and thus, the computed standard errors are robust to interdependence in cross country error terms. Numbers in parentheses indicate p- values. All regressions include dummies to control for time, country, industry and firm fixed effects. Sargan test is a test for the validity of instruments and is asymptotically distributed as $\chi 2$ under the null of valid instruments. If p-value $>0.05$, we confirm the validity of instruments. AR (2) is a test for the second-order serial correlation and is asymptotically distributed as $\mathrm{N}(0,1)$ under the null of no serial correlation. If p-value $>0.05$, we confirm of no serial correlation at order two in the first-differenced errors and the model is well specified. ${ }^{*}$,* and ${ }^{* * *}$ indicate significance at the $10 \%, 5 \%$ and $1 \%$ levels, respectively. 
and default risk, such as those prevalent in many MENA countries. This result is also consistent with Fan et al.'s (2012) finding and view that "debt is expected to be used relatively more than equity when the public sector is more corrupt, since it is easier to expropriate outside equity holders than debt holders"(p.27).

It is also worth noticing that including any of the institutional variables alters neither the statistical significance nor the economic magnitude of the firm-level variables' effects on leverage. This suggests that institutional factors play a significant impact on corporate leverage over-and-above the impact of firm-level factors, and point to the importance of institutional quality in firms' financing decisions in the MENA region. Overall, further financial sector development, better rule of law, and more regulatory effectiveness seem to enhance firms' access to external finance, in particular debt capital.

\subsection{Additional tests: indirect impact of institutions}

The results reported in Table 7 indicate that the quality of institutions has a direct impact on corporate leverage; in general, institutions of better quality lead firms to use more debt. In this section, we argue that institutional quality has not only a direct impact on leverage, but also an indirect one. The latter works through the impact of institutional quality on the way some firm-level factors affect leverage. Specifically, we conjecture that firm-size and collateral availability, which play a significant role in MENA firms' leverage decisions, become less important in relatively better institutional and contractual environments. In predicting the impact of firm size on leverage in MENA countries, we argued that larger firms are expected to use more debt as they may have more of the connections and the reputational capital necessary to circumvent a weak institutional environment characterizing most MENA countries. However, as the quality of the institutional environment improves, being a large firm may become less of an advantage to raise debt capital. In other words, in the presence of well-functioning institutions that secure property rights and guarantee abidance by the rule of law and a well-developed financial system, creditors may become less reluctant to extend credit to smaller firms, thereby increasing the latters' borrowing capacity. We, therefore, expect better quality institutions to mitigate the positive impact of size on corporate leverage. Likewise, we interpreted the strong positive association between asset tangibility and leverage, reported in Tables 6 and 7, as a natural outcome of the underdeveloped regulatory and contractual environment that characterizes most MENA countries; in an underdeveloped institutional framework, collateral is crucial to raising debt. Nevertheless, with improvements in this framework, access to credit may become less contingent upon the availability of collateral. Hence, corporate leverage may become less dependent on asset tangibility. We expect better institutional quality to mitigate the positive impact of TANG on leverage.

To estimate the potential indirect impact of institutions on leverage, we re-estimate leverage models presented in Table 7 augmented with interaction variables between the institutional quality measures and SIZE and between the institutional quality measures and TANG. The results on the indirect impact of institutions on book leverage through firm size are reported in Panel A of Table 8. Using market leverage yields qualitatively similar results. ${ }^{12}$ In column (1), we estimate the impact of financial development on the size-leverage relation by including an interaction variable between FD and SIZE in the leverage regression equation. While SIZE and FD continue to load positive and significant, the coefficient estimate on the interaction term is insignificant. This finding suggests that financial development has no impact on the way firm-size affects leverage; even as the financial system develops further, larger firms continue to operate with relatively more leverage, possibly due to their easier access to debt capital compared to smaller firms.

In column (2), we estimate the indirect impact of regulatory effectiveness on leverage by accounting for its potential effect on the size-leverage relation. We find that not only the coefficient estimates on SIZE and RE continue to load positive and significant, but also the coefficient estimate on the interaction term between SIZE and RE loads negative and significant, indicating that enhanced regulatory effectiveness attenuates the impact of firm size on leverage. In column (3), we estimate the indirect impact of the rule of law on leverage by considering its potential effect on the size-leverage relation. The results indicate that only SIZE and RL are positively associated to leverage. The coefficient estimate on the interaction term between SIZE and RL is, however, insignificant, implying that the rule of law plays only a direct impact on leverage. In column

${ }^{12}$ These results are unreported for the sake of brevity, but are available from the authors upon request. 
(4), we estimate the indirect impact of corruption on leverage by accounting for its potential effect on the size-leverage relation. Our findings indicate that corruption has neither a direct nor an indirect effect on book leverage. SIZE, however, continues to be positively and significantly associated with book leverage.

Table 8

Indirect impact of institutions on book leverage (BVD).

\begin{tabular}{|c|c|c|c|c|c|c|c|c|}
\hline & $(1)$ & $(2)$ & (3) & (4) & $(5)$ & $(6)$ & (7) & $(8)$ \\
\hline & \multicolumn{4}{|c|}{ Panel A: Firm Size (SIZE) } & \multicolumn{4}{|c|}{ Panel B: Asset Tangibility (TANG) } \\
\hline Debt $(\mathrm{t}-1)$ & $\begin{array}{l}0.571^{* * * *} \\
(0.000)\end{array}$ & $\begin{array}{l}0.563^{* * *} \\
(0.000)\end{array}$ & $\begin{array}{l}0.553^{* * *} \\
(0.000)\end{array}$ & $\begin{array}{l}0.574^{* * *} \\
(0.000)\end{array}$ & $\begin{array}{l}0.571^{* * * *} \\
(0.000)\end{array}$ & $\begin{array}{l}0.552^{* * * *} \\
(0.000)\end{array}$ & $\begin{array}{l}0.521^{* * * *} \\
(0.000)\end{array}$ & $\begin{array}{l}0.546^{* * *} \\
(0.000)\end{array}$ \\
\hline SIZE & $\begin{array}{l}0.067^{* *} \\
(0.000)\end{array}$ & $\begin{array}{l}0.068^{* * * *} \\
(0.000)\end{array}$ & $\begin{array}{l}0.053^{* * *} \\
(0.000)\end{array}$ & $\begin{array}{l}0.068^{* * *} \\
(0.000)\end{array}$ & $\begin{array}{l}0.067^{* * * *} \\
(0.000)\end{array}$ & $\begin{array}{l}0.075^{* * * *} \\
(0.000)\end{array}$ & $\begin{array}{l}0.066 \text { **** } \\
(0.000)\end{array}$ & $\begin{array}{l}0.066^{* * *} \\
(0.000)\end{array}$ \\
\hline TANG & $\begin{array}{l}0.172^{* *} \\
(0.045)\end{array}$ & $\begin{array}{l}0.201^{* *} \\
(0.043)\end{array}$ & $\begin{array}{l}0.179 * * \\
(0.032)\end{array}$ & $\begin{array}{l}0.170^{* *} \\
(0.042)\end{array}$ & $\begin{array}{l}0.123^{* *} \\
(0.038)\end{array}$ & $\begin{array}{l}0.156^{* *} \\
(0.043)\end{array}$ & $\begin{array}{l}0.104^{* * *} \\
(0.001)\end{array}$ & $\begin{array}{l}0.129^{* *} \\
(0.040)\end{array}$ \\
\hline PROF & $\begin{array}{l}-0.196^{* * *} \\
(0.000)\end{array}$ & $\begin{array}{l}-0.194^{* * *} \\
(0.000)\end{array}$ & $\begin{array}{l}-0.200^{* * *} \\
(0.000)\end{array}$ & $\begin{array}{l}-0.200^{* * * *} \\
(0.000)\end{array}$ & $\begin{array}{l}-0.195^{* * *} \\
(0.001)\end{array}$ & $\begin{array}{l}-0.201^{* * *} \\
(0.000)\end{array}$ & $\begin{array}{l}-0.205^{* * *} \\
(0.000)\end{array}$ & $\begin{array}{l}-0.201^{* * *} \\
(0.000)\end{array}$ \\
\hline TAX & $\begin{array}{l}0.000 \\
(0.591)\end{array}$ & $\begin{array}{l}0.000 \\
(0.550)\end{array}$ & $\begin{array}{l}0.000 \\
(0.794)\end{array}$ & $\begin{array}{l}0.000 \\
(0.587)\end{array}$ & $\begin{array}{l}0.000 \\
(0.598)\end{array}$ & $\begin{array}{l}0.000 \\
(0.526)\end{array}$ & $\begin{array}{l}0.000 \\
(0.563)\end{array}$ & $\begin{array}{l}0.000 \\
(0.533)\end{array}$ \\
\hline Z-score & $\begin{array}{l}-0.108^{* * *} \\
(0.000)\end{array}$ & $\begin{array}{l}-0.107^{* * *} \\
(0.000)\end{array}$ & $\begin{array}{l}-0.108^{* * *} \\
(0.000)\end{array}$ & $\begin{array}{l}-0.108^{* * *} \\
(0.000)\end{array}$ & $\begin{array}{l}-0.160^{* * *} \\
(0.000)\end{array}$ & $\begin{array}{l}-0.108^{* * *} \\
(0.000)\end{array}$ & $\begin{array}{l}-0.128^{* * *} \\
(0.000)\end{array}$ & $\begin{array}{l}-0.108^{* * *} \\
(0.000)\end{array}$ \\
\hline LIQ & $\begin{array}{l}-0.460^{* * *} \\
(0.000)\end{array}$ & $\begin{array}{l}-0.469^{* * *} \\
(0.000)\end{array}$ & $\begin{array}{l}-0.456^{* * *} \\
(0.000)\end{array}$ & $\begin{array}{l}-0.461^{* * *} \\
(0.000)\end{array}$ & $\begin{array}{l}-0.443^{* * *} \\
(0.000)\end{array}$ & $\begin{array}{l}-0.452^{* * * *} \\
(0.000)\end{array}$ & $\begin{array}{l}-0.449^{* * *} \\
(0.000)\end{array}$ & $\begin{array}{l}-0.453^{* * *} \\
(0.000)\end{array}$ \\
\hline GROW & $\begin{array}{l}0.000 \\
(0.252)\end{array}$ & $\begin{array}{l}0.000 \\
(0.220)\end{array}$ & $\begin{array}{l}0.000 \\
(0.210)\end{array}$ & $\begin{array}{l}0.000 \\
(0.228)\end{array}$ & $\begin{array}{l}0.000 \\
(0.259)\end{array}$ & $\begin{array}{l}0.000 \\
(0.189)\end{array}$ & $\begin{array}{l}0.000 \\
(0.188)\end{array}$ & $\begin{array}{l}0.000 \\
(0.218)\end{array}$ \\
\hline RGDP & $\begin{array}{l}0.363^{* * * *} \\
(0.000)\end{array}$ & $\begin{array}{l}0.426^{* * *} \\
(0.000)\end{array}$ & $\begin{array}{l}0.408^{* * * *} \\
(0.002)\end{array}$ & $\begin{array}{l}0.388^{* * * *} \\
(0.000)\end{array}$ & $\begin{array}{l}0.362^{* * * *} \\
(0.000)\end{array}$ & $\begin{array}{l}0428^{* * * *} \\
(0.000)\end{array}$ & $\begin{array}{l}0.390^{* * * *} \\
(0.001)\end{array}$ & $\begin{array}{l}0.381^{* * * *} \\
(0.000)\end{array}$ \\
\hline INF & $\begin{array}{l}0.066^{*} \\
(0.091) \\
0.020^{* *}\end{array}$ & $\begin{array}{l}0.073^{* *} \\
(0.048)\end{array}$ & $\begin{array}{l}0.042^{* *} \\
(0.028)\end{array}$ & $\begin{array}{l}0.057^{* *} \\
(0.016)\end{array}$ & $\begin{array}{l}0.065^{*} \\
(0.082) \\
0.015^{* *}\end{array}$ & $\begin{array}{l}0.073^{*} \\
(0.094)\end{array}$ & $\begin{array}{l}0.088^{* *} \\
(0.029)\end{array}$ & $\begin{array}{l}0.059^{* *} \\
(0.038)\end{array}$ \\
\hline FD & $(0.026)$ & & & & $(0.031)$ & & & \\
\hline $\mathrm{RE}$ & & $\begin{array}{l}0.306^{* *} \\
(0.029)\end{array}$ & & & & $\begin{array}{l}0.331^{* *} \\
(0.049)\end{array}$ & & \\
\hline RL & & & $\begin{array}{l}0.272^{* *} \\
(0.038)\end{array}$ & & & & $\begin{array}{l}0.164^{* * *} \\
(0.000)\end{array}$ & \\
\hline CORR & & & & $\begin{array}{l}-0.043 \\
(0.598)\end{array}$ & & & & $\begin{array}{l}-0.057^{* * *} \\
(0.000)\end{array}$ \\
\hline $\mathrm{FD} \times \mathrm{SIZE} / \mathrm{TANG}$ & $\begin{array}{l}-0.005 \\
(0.604)\end{array}$ & & & & $\begin{array}{l}-0.019 \\
(0.322)\end{array}$ & & & \\
\hline $\mathrm{RE} \times \mathrm{SIZE} / \mathrm{TANG}$ & & $\begin{array}{l}-0.051^{* *} \\
(0.042)\end{array}$ & & & & $\begin{array}{l}-0.230^{* * *} \\
(0.000)\end{array}$ & & \\
\hline $\mathrm{RL} \times \mathrm{SIZE} / \mathrm{TANG}$ & & & $\begin{array}{l}-0.061 \\
(0.020)\end{array}$ & & & & $\begin{array}{l}-0.355^{* * *} \\
(0.000)\end{array}$ & \\
\hline CORR $\times$ SIZE $/$ TANG & & & & $\begin{array}{l}-0.008 \\
(0.588)\end{array}$ & & & & $\begin{array}{l}-0.149^{* * *} \\
(0.001)\end{array}$ \\
\hline Intercept & $\begin{array}{l}0.073 \\
(0.352)\end{array}$ & $\begin{array}{l}0.072 \\
(0.340)\end{array}$ & $\begin{array}{l}0.055 \\
(0.376)\end{array}$ & $\begin{array}{l}0.082 \\
(0.239)\end{array}$ & $\begin{array}{l}0.069 \\
(0.308)\end{array}$ & $0.115(0.103)$ & $\begin{array}{l}-0.091 \\
(0.168)\end{array}$ & $\begin{array}{l}0.066 \\
(0.320)\end{array}$ \\
\hline Sargan test & $\begin{array}{l}19.99 \\
(0.129)\end{array}$ & $\begin{array}{l}19.335^{*} \\
(0.061)\end{array}$ & $\begin{array}{l}18.272^{*} \\
(0.075)\end{array}$ & $\begin{array}{l}19.198 \\
(0.062)\end{array}$ & $\begin{array}{l}19.578 \\
(0.330)\end{array}$ & $\begin{array}{l}19.207^{*} \\
(0.072)\end{array}$ & $\begin{array}{l}18.293^{*} \\
(0.075)\end{array}$ & $\begin{array}{l}21.175^{* *} \\
(0.042)\end{array}$ \\
\hline AR (2) test & $\begin{array}{l}0.505 \\
(0.613)\end{array}$ & $\begin{array}{l}0.4834 \\
(0.628)\end{array}$ & $\begin{array}{l}0.458 \\
(0.646)\end{array}$ & $\begin{array}{l}0.473 \\
(0.636)\end{array}$ & $\begin{array}{l}0.534 \\
(0.593)\end{array}$ & $\begin{array}{l}0.503 \\
(0.614)\end{array}$ & $\begin{array}{l}0.742 \\
(0.457\end{array}$ & $\begin{array}{l}0.4928 \\
(0.622)\end{array}$ \\
\hline
\end{tabular}

Notes: This table presents regression results of how the interactions between institutional environments and firm size effect of debt ratio across countries. See Table 1 and for the definition of the variables. The data set is a panel consists of 3717 firm-year observations representing 444 firms from 10 MENA countries over the period 2003-2011. The regressions are estimated using the two-step system GMM estimator of Arellano and Bover (1995) and Blundell and Bond (1998) with Windmeijer (2005) small-sample correction method. The t-2 lags of the variables used as instruments in the difference equation, and the same lags of differenced variables are used in the levels equation. All models are estimated with a switched on clustering option and thus, the computed standard errors are robust to interdependence in cross country error terms. Numbers in Numbers in parentheses indicate p- values. All regressions include dummies to control for time, country, industry and firm fixed effects. Sargan test is a test for the validity of instruments and is asymptotically distributed as $\chi 2$ under the null of valid instruments. If p-value $>0.05$, we confirm the validity of instruments. AR (2) is a test for the second-order serial correlation and is asymptotically distributed as $\mathrm{N}(0,1)$ under the null of no serial correlation. If p-value $>0.05$, we confirm of no serial correlation at order two in the first-differenced errors and the model is well specified. * ** and ${ }^{* * *}$ indicate significance at the $10 \%, 5 \%$ and $1 \%$ levels, respectively. 
In panel B of Table 8, we report the results of the estimations of the indirect impact of institutions on book leverage through asset tangibility. Again, unreported market leverage results are qualitatively the same. In column (5), we find that FD and SIZE continue to be positively associated with leverage, whereas the interaction term between FD and TANG has no significant impact on leverage. In column (6), we report a positive coefficient estimate on RE as well as on TANG, and a negative coefficient estimate on the interaction term between RE and TANG. This finding suggests that more regulatory effectiveness mitigates firms' need for more collateral to be able to operate with higher leverage ratios. In column (7), we find that the rule of law has both direct and indirect impacts on firm leverage; the coefficient estimate on RL is positive and significant and the coefficient estimate on the interaction term between RL and TANG is negative and significant. This implies that a stronger rule of law lowers the impact of asset tangibility on leverage. In column (8), we find that the interaction term between CORR and TANG is negative and significant, implying that as corruption diminishes - higher CORR -, the impact of asset tangibility on firm leverage decreases. Notice also that the magnitude and statistical significance of the direct impact of CORR has also increased relative to the specification with no interaction term, reported in column (6) of Table 7. The overall message from column (8) is that while better corruption control lowers leverage it also reduces the impact of asset tangibility on leverage.

To summarize, the evidence in Tables 7 and 8 indicates that institutions in the MENA region have two types of impacts on corporate leverage: a direct impact and an indirect one. The direct impact suggests that better quality institutions, namely a more developed financial system, better regulatory effectiveness, and stronger rule of law, lead to the use of more debt by firms. The indirect impact suggests that better institutions also attenuate the impact of the way firm-level factors, namely size and assets tangibility, affect corporate leverage.

\subsection{Robustness checks}

In Table 9, we present additional tests intended to ensure the robustness of our results to alternative measures of leverage, tax shields, and sample composition. In panel A, we use the long-term debt ratio (LTDR) as our measure of leverage. A specific long-term debt ratio rather than a ratio of total debt may be the target towards which firms attempt to adjust over time. Column (1)-(4) show that our conclusions on the impact of our firm- and country-level variables on MENA firms' leverage continue to hold when we use long-term debt rather than total debt as a measure of leverage. In panels B, C, and D of Table 9, we report results based on BVD as a measure of financial leverage. Results - unreported for the sake of space - are qualitatively the same when we use MVD. In panel B, we use non-debt tax shields (TAX1) measured by the ratio of depreciation and amortization to total assets as an alternative to TAX. Using BVD as our dependent variable, we find that whereas TAX1 appears insignificant throughout columns (5) to (8), all other variables retain their initial signs and significance, indicating that using non-debt tax shields as an explanatory variable does not affect the robustness of our findings.

In panel C of Table 9, we follow Graham et al. (2014) and exclude regulated industries - utilities and transportation companies - from our sample. Results presented in columns (9) to (12) suggest that our conclusions are not driven by the presence of regulated industries in our sample as we continue to report the same relations between our firm- and country-level variables and financial leverage. In panel D, we exclude Egypt from our sample to ensure that our results are not driven by the relatively heavy weight of Egyptian firms in our sample (22.5\% of total observations). Results reported in columns (13) to (16) indicate that our conclusions are not driven by the presence of Egypt in the Sample.

\section{Conclusion}

An increasing number of studies have been highlighting the importance of a country's institutional and contractual framework to firms' capital structure decisions. In this paper, we investigate the state of firm leverage in a region that has not been covered by prior research: the MENA region. We particularly focus on two issues: (1) whether firm-level factors - size, profitability, asset tangibility, growth, etc. - are associated with leverage as predicted by major capital structure theories, and in similar ways to the findings of previous research work on other countries and regions, and (2) whether countries' institutional frameworks play a role in firms' capital structure decisions.

Our findings suggest that MENA firms operate with leverage ratios which are not much different from those observed in countries from other parts of the world. Moreover, we document evidence that MENA 
Table 9

Robustness tests.

\begin{tabular}{|c|c|c|c|c|c|c|c|c|}
\hline & (1) & (2) & (3) & (4) & (5) & (6) & (7) & (8) \\
\hline & \multicolumn{4}{|c|}{ Panel A: Long-term debt ratio (LTDR) } & \multicolumn{4}{|c|}{ Panel B: Non-debt tax shields (TAX1) } \\
\hline Debt $(t-1)$ & $\begin{array}{l}0.217^{* * *} \\
(0.000)\end{array}$ & $\begin{array}{l}0.228^{* * *} \\
(0.000)\end{array}$ & $\begin{array}{l}0.222^{* * *} \\
(0.000)\end{array}$ & $\begin{array}{l}0.218^{* * *} \\
(0.000)\end{array}$ & $\begin{array}{l}0.568^{* * *} \\
(0.000)\end{array}$ & $\begin{array}{l}0.554^{* * *} \\
(0.000)\end{array}$ & $\begin{array}{l}0.553^{* * *} \\
(0.000)\end{array}$ & $\begin{array}{l}0.549^{* * *} \\
(0.000)\end{array}$ \\
\hline SIZE & $\begin{array}{l}0.109^{* *} \\
(0.003)\end{array}$ & $\begin{array}{l}0.100^{* *} \\
(0.045)\end{array}$ & $\begin{array}{l}0.106^{* *} \\
(0.047)\end{array}$ & $\begin{array}{l}0.105^{* *} \\
(0.037)\end{array}$ & $\begin{array}{l}0.063^{* * *} \\
(0.001)\end{array}$ & $\begin{array}{l}0.068^{* * *} \\
(0.001)\end{array}$ & $\begin{array}{l}0.061^{* * *} \\
(0.002)\end{array}$ & $\begin{array}{l}0.062^{* * *} \\
(0.310)\end{array}$ \\
\hline TANG & $\begin{array}{l}0.565 * * * \\
(0.000)\end{array}$ & $\begin{array}{l}0.606^{* * * *} \\
(0.000)\end{array}$ & $\begin{array}{l}0.684^{* * *} \\
(0.000)\end{array}$ & $\begin{array}{l}0.681^{* * * *} \\
(0.002)\end{array}$ & $\begin{array}{l}0.150^{* *} \\
(0.031)\end{array}$ & $\begin{array}{l}0.121^{* * *} \\
(0.033)\end{array}$ & $\begin{array}{l}0.126^{* * *} \\
(0.035)\end{array}$ & $\begin{array}{l}0.001^{* * * *} \\
(0.038)\end{array}$ \\
\hline PROF & $\begin{array}{l}-0.706^{* * *} \\
(0.000)\end{array}$ & $\begin{array}{l}-0.702^{* * *} \\
(0.000)\end{array}$ & $\begin{array}{l}-0.700^{* * *} \\
(0.000)\end{array}$ & $\begin{array}{l}-0.706^{* * *} \\
(0.000)\end{array}$ & $\begin{array}{l}-0.245 \\
(0.000)\end{array}$ & $\begin{array}{l}-0.236 \\
(0.000)\end{array}$ & $\begin{array}{l}-0.237 \\
(0.000)\end{array}$ & $\begin{array}{l}-0.234 \\
(0.000)\end{array}$ \\
\hline TAX & $\begin{array}{l}0.294^{* * * *} \\
(0.000)\end{array}$ & $\begin{array}{l}0.296^{* * *} \\
(0.000)\end{array}$ & $\begin{array}{l}0.293 * * * \\
(0.000)\end{array}$ & $\begin{array}{l}0.293^{* * *} \\
(0.000)\end{array}$ & $\begin{array}{l}-0.009 \\
(0.406)\end{array}$ & $\begin{array}{l}-0.009 \\
(0.437)\end{array}$ & $\begin{array}{l}-0.008 \\
(0.484)\end{array}$ & $\begin{array}{l}-0.009 \\
(0.481)\end{array}$ \\
\hline Z-Score & $\begin{array}{l}0.072^{* * * *} \\
(0.000)\end{array}$ & $\begin{array}{l}0.085^{* * * *} \\
(0.000)\end{array}$ & $\begin{array}{l}0.082^{* * * *} \\
(0.000)\end{array}$ & $\begin{array}{l}0.085^{* * *} \\
(0.000)\end{array}$ & $\begin{array}{l}-0.149^{* * *} \\
(0.000)\end{array}$ & $\begin{array}{l}-0.146^{* * *} \\
(0.000)\end{array}$ & $\begin{array}{l}-0.147^{* * *} \\
(0.000)\end{array}$ & $\begin{array}{l}-0.146^{* * *} \\
(0.000)\end{array}$ \\
\hline LIQ & $\begin{array}{l}-0.303^{* * *} \\
(0.000)\end{array}$ & $\begin{array}{l}-0.261^{* * *} \\
(0.000)\end{array}$ & $\begin{array}{l}-0.267^{* * *} \\
(0.000)\end{array}$ & $\begin{array}{l}-0.254^{* * *} \\
(0.008)\end{array}$ & $\begin{array}{l}-0.453^{* *} \\
(0.012)\end{array}$ & $\begin{array}{l}-0.484^{* * *} \\
(0.009)\end{array}$ & $\begin{array}{l}-0.497^{* * *} \\
(0.008)\end{array}$ & $\begin{array}{l}-0.488^{* * *} \\
(0.009)\end{array}$ \\
\hline GROW & $\begin{array}{l}-0.016^{* * * *} \\
(0.000)\end{array}$ & $\begin{array}{l}-0.010^{* * * *} \\
(0.000)\end{array}$ & $\begin{array}{l}-0.018^{* * * *} \\
(0.000)\end{array}$ & $\begin{array}{l}-0.016^{* * *} \\
(0.000)\end{array}$ & $\begin{array}{l}0.000 \\
(0.261)\end{array}$ & $\begin{array}{l}0.000 \\
(0.183)\end{array}$ & $\begin{array}{l}0.000 \\
(0.181)\end{array}$ & $\begin{array}{l}0.000 \\
(0.229)\end{array}$ \\
\hline RGDP & $\begin{array}{l}0.231^{*} \\
(0.089)\end{array}$ & $\begin{array}{l}0.245^{*} \\
(0.087)\end{array}$ & $\begin{array}{l}0.257^{*} \\
(0.072)\end{array}$ & $\begin{array}{l}0.297^{*} \\
(0.082)\end{array}$ & $\begin{array}{l}0.271^{* * * *} \\
(0.000)\end{array}$ & $\begin{array}{l}0.263^{* * *} \\
(0.001)\end{array}$ & $\begin{array}{l}0.274^{* * *} \\
(0.000)\end{array}$ & $\begin{array}{l}0.272^{* * *} \\
(0.000)\end{array}$ \\
\hline INF & $\begin{array}{l}-0.203 \\
(0.126)\end{array}$ & $\begin{array}{l}-0.257 \\
(0.163)\end{array}$ & $\begin{array}{l}-0.298 \\
(0.115)\end{array}$ & $\begin{array}{l}-0.276 \\
(0.121)\end{array}$ & $\begin{array}{l}0.080^{* *} \\
(0.035)\end{array}$ & $\begin{array}{l}0.079^{* *} \\
(0.035)\end{array}$ & $\begin{array}{l}0.076^{* *} \\
(0.036)\end{array}$ & $\begin{array}{l}0.082^{* *} \\
(0.033)\end{array}$ \\
\hline FD & $\begin{array}{l}0.062^{* *} \\
(0.004)\end{array}$ & & & & $\begin{array}{l}0.018^{* *} \\
(0.050)\end{array}$ & & & \\
\hline RE & & $\begin{array}{l}0.865^{* * * *} \\
(0.000)\end{array}$ & & & & $\begin{array}{l}0.036^{* *} \\
(0.043)\end{array}$ & & \\
\hline RL & & & $\begin{array}{l}0.647^{* * * *} \\
(0.000)\end{array}$ & & & & $\begin{array}{l}0.019^{* * * *} \\
(0.002)\end{array}$ & \\
\hline CORR & & & & $\begin{array}{l}-0.254^{* * *} \\
(0.001)\end{array}$ & & & & $\begin{array}{l}-0.052^{* * *} \\
(0.000)\end{array}$ \\
\hline Intercept & $\begin{array}{l}0.213^{*} \\
(0.059)\end{array}$ & $\begin{array}{l}0.298^{*} \\
(0.069)\end{array}$ & $\begin{array}{l}0.250^{*} \\
(0.095)\end{array}$ & $\begin{array}{l}0.282^{*} \\
(0.085)\end{array}$ & $\begin{array}{l}0.129 \\
(0.459)\end{array}$ & $\begin{array}{l}0.155 \\
(0.371)\end{array}$ & $\begin{array}{l}0.138 \\
(0.426)\end{array}$ & $\begin{array}{l}0.136 \\
(0.433)\end{array}$ \\
\hline Sargan test & $\begin{array}{l}34.168 \\
0.528\end{array}$ & $\begin{array}{l}31.258 \\
(0.598)\end{array}$ & $\begin{array}{l}37.346 \\
(0.451)\end{array}$ & $\begin{array}{l}36.990 \\
(0.460)\end{array}$ & $\begin{array}{l}20.096^{*} \\
(0.530)\end{array}$ & $\begin{array}{l}21.062^{* *} \\
(0.048)\end{array}$ & $\begin{array}{l}20.672^{*} \\
(0.055)\end{array}$ & $\begin{array}{l}20.934^{*} \\
(0.051)\end{array}$ \\
\hline AR (2) test & $\begin{array}{l}0.2458 \\
(0.805)\end{array}$ & $\begin{array}{l}0.161 \\
(0.871)\end{array}$ & $\begin{array}{l}0.191 \\
(0.848)\end{array}$ & $\begin{array}{l}0.170 \\
(0.864)\end{array}$ & $\begin{array}{l}0.452 \\
(0.651)\end{array}$ & $\begin{array}{l}0.412 \\
(0.679)\end{array}$ & $\begin{array}{l}0.416 \\
(0.677)\end{array}$ & $\begin{array}{l}0.404 \\
(0.686)\end{array}$ \\
\hline
\end{tabular}

Notes: This table presents additional regression results of firm- country- and institutional specific determinants of debt ratio across countries. See Table 1 and for the definition of the variables. In Panel A, models (1)-(4) replicate models (3)-(6) of Table 6 using Long-term debt ratio (LTDR) as the dependent variable instead of Book value of total debt ratio (BVD). In these models, the data set is a panel consists of 3717 firm-year observations representing 444 firms from 10 MENA countries over the period 2003-2011. In Panel B, models (5)(8) replicate models (3)-(6) of Table 6 using Non-debt tax shields (TAX1) as explanatory variable instead of debt tax shields (TAX). In these models, the data set is a panel consists of 3717 firm-year observations representing 444 firms from 10 MENA countries over the period 2003-2011. In Panel C, models (9)-(12) replicate models (3)-(6) of Table 6 excluded Egypt from the sample. In these models, the analysis ended with a sample contains 361 firms for a total of 3249 firm-year observations. In Panel D, models (13)-(16) replicate models (3)-(6) of Table 6 excluded regulated industries (Transportation and Utilities industries) from the sample. In these models, the analysis ended with a sample contains 406 firms for a total of 3654 firm-year observations. The regressions are estimated using the two-step system GMM estimator of Arellano and Bover (1995) and Blundell and Bond (1998) with Windmeijer (2005) small-sample correction method. The t-2 lags of the variables used as instruments in the difference equation, and the same lags of differenced variables are used in the levels equation. All models are estimated with a switched on clustering option and thus, the computed standard errors are robust to interdependence in cross country error terms. Numbers in Numbers in parentheses indicate p-values. All regressions include dummies to control for time, country, industry and firm fixed effects. Sargan test is a test for the validity of instruments and is asymptotically distributed as $\chi 2$ under the null of valid instruments. If $p$-value $>0.05$, we confirm the validity of instruments. AR (2) is a test for the second-order serial correlation and is asymptotically distributed as $\mathrm{N}(0,1)$ under the null of no serial correlation. If $\mathrm{p}$-value $>0.05$, we confirm of no serial correlation at order two in the first-differenced errors and the model is well specified. ${ }^{*}{ }^{* *}$ and ${ }^{* * *}$ indicate significance at the $10 \%, 5 \%$ and $1 \%$ levels, respectively.

firms have target capital structures towards which they adjust partially over time. Yet, adjustment speeds vary from one country to another, possibly reflecting differences in institutional environments across MENA countries. We also find that size, asset tangibility, profitability, taxes, and growth are associated with 


\begin{tabular}{|c|c|c|c|c|c|c|c|}
\hline (9) & $(10)$ & (11) & $(12)$ & $(13)$ & $(14)$ & $(15)$ & $(16)$ \\
\hline \multicolumn{4}{|c|}{ Panel C: Excluded regulated industries from the sample } & \multicolumn{4}{|c|}{ Panel D: Excluded Egypt from the sample } \\
\hline $0.640^{* * *}$ & $0.621^{* * *}$ & $0.607^{* * *}$ & $0.623^{* * *}$ & $0.564^{* * *}$ & $0.561^{* * *}$ & $0.549^{* * *}$ & $0.561^{* * *}$ \\
\hline$(0.000)$ & $(0.000)$ & $(0.000)$ & $(0.000)$ & $(0.000)$ & $(0.000)$ & $(0.000)$ & $(0.000)$ \\
\hline $0.061^{* * *}$ & $0.109^{* * *}$ & $0.110^{* * *}$ & $0.107^{* * * *}$ & $0.041^{* * *}$ & $0.048^{* * *}$ & $0.040^{* * *}$ & $0.049^{* * *}$ \\
\hline$(0.005)$ & $(0.006)$ & $(0.005)$ & $(0.006)$ & $(0.002)$ & $(0.007)$ & $(0.001)$ & $(0.002)$ \\
\hline $0.122^{* *}$ & $0.119^{* *}$ & $0.118^{* *}$ & $0.118^{* *}$ & $0.104^{*}$ & $0.104^{*}$ & $0.102^{* *}$ & $0.103^{*}$ \\
\hline$(0.050)$ & $(0.054)$ & $(0.056)$ & $(0.055)$ & $(0.069)$ & $(0.064)$ & $(0.038)$ & $(0.051)$ \\
\hline$-0.207^{* * *}$ & $0.208^{* * *}$ & $0.217^{* * *}$ & $0.214^{* * * *}$ & $-0.276^{* * *}$ & $-0.311^{* * *}$ & $-0.322^{* * *}$ & $-0.311^{* * *}$ \\
\hline$(0.002)$ & $(0.002)$ & $(0.002)$ & $(0.002)$ & $(0.000)$ & $(0.000)$ & $(0.000)$ & $(0.000)$ \\
\hline 0.000 & 0.000 & 0.000 & 0.000 & 0.000 & 0.000 & 0.000 & 0.000 \\
\hline$(0.119)$ & $(0.135)$ & $(0.196)$ & $(0.157)$ & $(0.679)$ & $(0.846)$ & $(0.561)$ & $(0.415)$ \\
\hline$-0.193^{* * *}$ & $-0.192^{* * * *}$ & $-0.194^{* * *}$ & $-0.194^{* * *}$ & $-0.167^{* * *}$ & $-0.168^{* * *}$ & $-0.174^{* * *}$ & $-0.170^{* * *}$ \\
\hline$(0.000)$ & $(0.000)$ & $(0.000)$ & $(0.000)$ & $(0.000)$ & $(0.000)$ & $(0.000)$ & $(0.000)$ \\
\hline$-0.503^{* * *}$ & $-0.496^{* * *}$ & $-0.494^{* * *}$ & $-0.497^{* * *}$ & $-0.549^{* * *}$ & $-0.578^{* * *}$ & $-0.553^{* * *}$ & $-0.552^{* * *}$ \\
\hline$(0.000)$ & $(0.000)$ & $(0.000)$ & $(0.000)$ & $(0.000)$ & $(0.000)$ & $(0.000)$ & $(0.000)$ \\
\hline 0.000 & 0.000 & 0.000 & 0.000 & 0.000 & 0.000 & 0.000 & $0.000^{*}$ \\
\hline$(0.101)$ & $(0.124)$ & $(0.125)$ & $(0.123)$ & $(0.101)$ & $(0.136)$ & $(0.120)$ & $(0.091)$ \\
\hline $0.345^{* * * *}$ & $0.343^{* * *}$ & $0.333^{* * *}$ & $0.332^{* * *}$ & $0.151^{* *}$ & $0.163^{* *}$ & $0.290^{* *}$ & $0.166^{* *}$ \\
\hline$(0.001)$ & $(0.002)$ & $(0.001)$ & $(0.001)$ & $(0.035)$ & $(0.021)$ & $(0.020)$ & $(0.021)$ \\
\hline \multirow{9}{*}{$\begin{array}{l}0.059^{*} \\
(0.065) \\
0.042^{* * *} \\
(0.003)\end{array}$} & $0.049^{* *}$ & $0.040^{* *}$ & $0.060^{*}$ & $0.084^{* *}$ & $0.074^{* *}$ & $0.078^{* *}$ & $0.074^{* *}$ \\
\hline & $(0.059)$ & $(0.046)$ & $(0.550)$ & $(0.036)$ & $(0.043)$ & $(0.037)$ & $(0.042)$ \\
\hline & & & & $(0.001)$ & & & \\
\hline & $0.067^{* *}$ & & & & $0.044^{* *}$ & & \\
\hline & $(0.036)$ & & & & $(0.013)$ & & \\
\hline & & $0.038^{* *}$ & & & & $0.041^{* * *}$ & \\
\hline & & $(0.044)$ & & & & $(0.008)$ & \\
\hline & & & $-0.018^{*}$ & & & & -0.003 \\
\hline & & & $(0.053)$ & & & & $(0.697)$ \\
\hline $0.440^{*}$ & $0.403^{*}$ & $0.411^{*}$ & $0.399 *$ & $0.405^{*}$ & $0.365^{*}$ & $0.306^{*}$ & $0.413^{*}$ \\
\hline$(0.062)$ & $(0.086)$ & $(0.081)$ & $(0.090)$ & $(0.072)$ & $(0.072)$ & $(0.076)$ & $(0.074)$ \\
\hline 18.277 & 19.809 & 18.852 & 19.704 & 26.264 & 26.809 & 26.606 & 26.332 \\
\hline$(0.508)$ & $(0.439)$ & $(0.459)$ & $(0.543)$ & $(0.134)$ & $(0.145)$ & $(0.129)$ & $(0.134)$ \\
\hline 0.900 & 0.905 & 0.889 & 0.900 & 0.796 & 0.738 & 0.764 & 0.756 \\
\hline$(0.368)$ & $(0.365)$ & $(0.373)$ & $(0.368)$ & $(0.522)$ & $(0.482)$ & $(0.493)$ & $(0.468)$ \\
\hline
\end{tabular}

leverage consistent with the trade-off and pecking order theories of capital structure and the findings of prior research on firms located in other countries and regions. When we use a cross-country setting to account for the potential impact of institutional quality on firm leverage, we find robust evidence that better institutional 
quality leads firms to use more debt. Specifically, firms operating in countries with relatively more developed financial systems, stronger rule of law, and more regulatory effectiveness operate with greater financial leverage. More corruption also leads to greater leverage, possibly because it helps in overcoming hurdles, to access to loans, due to deficient collateral and bankruptcy regimes that characterize most MENA countries.

Our findings add to the capital structure literature in two important ways. First, we enrich the growing cross-country capital structure body of research by presenting evidence from a geographical region that has not received attention in prior literature. This evidence suggests that a country's institutional quality matters to corporate capital structure decisions. Second, we add to the literature that focuses on emerging markets by highlighting the importance of improving developing countries' institutional environments for the sake of better access to external finance by firms.

\section{Acknowledgments}

We are grateful to Sadok El Ghoul, Omrane Guedhami, Tânia Montenegro, and two anonymous referees for very useful comments on earlier version of this paper. Any remaining errors are our own.

\section{References}

Adam, T., Goyal, V.K., 2008. The investment opportunity set and its proxy variables. J. Financ. Res. 31 (1), 41-63.

Alvarez de la Campa, 2011. Increasing Access to Credit Through Reforming Secured Transactions in the MENA Region, World Bank. ( World Bank (https://openknowledge.worldbank.org/handle/10986/3379 License: Creative Commons Attribution CC BY 3.0.").

Antoniou, A., Guney, Y., Paudyal, K., 2008. The determinants of capital structure: capital market-oriented versus bank-oriented institutions. J. Financ. Quant. Anal. 43 (1), 59-92.

Anzoategui, D., Piera, M.S., Rocha, R., 2010. Bank competition in the middle east and north Africa region. Rev. Middle East Econ. Financ. 6 (2), 2. Araujo, A., Ferreira, R., Funchal, B., 2012. The Brazilian bankrupcy law experience. J. Corp. Financ. 18 (4), 994-1004.

Arellano, M., Bover, O., 1995. Another look at the instrumental variable estimation of error-components models. Journal of econometrics 68 (1), 29-51.

Baker, M., Wurgler, J., 2002. Market timing and capital structure. J. Financ. 57, 1-32.

Bancel, F., Mittoo, U.R., 2004. Cross-country determinants of capital structure choice. A survey of European firms. Financ. Manag. 33 , $103-132$.

Barnea, A., Haugen, A., Senbet, L., 1981. Market imperfections, agency problems, and capital structure: a review. Financ. Manag. 10 (3), 7-22.

Ben Naceur, Omran, M., 2011. The effects of bank regulations, competition, and financial reforms on bank's performance. Emerg. Mark. Rev. 12 (1), 1-20.

Ben Naceur, S., Ghazouani, S., Omran, M., 2008. Does market liberalization spur financial and economic development in the MENA region? J. Comp. Econ. 36 (4), 673-693.

Blundell, R., Bond, S., 1998. Initial conditions and moment restrictions in dynamic panel data models. Journal of econometrics 87 (1), 115-143.

Booth, L., Aivazian, V., Demirguc-Kunt, A., Maksomovic, V., 2001. Capital structure in developing countries. J. Financ. 56, 87-130.

Bourgain, A., Pieretti, P., Zanaj, S., 2012. Financial openness, disclosure and bank risk-taking in MENA countries. Emerg. Mark. Rev. 13 (3), 283-300.

Business, D., 2013. Doing Business 2013-Smarter Regulations for Small and Medium-Size Enterprises. The World Bank. Abgerufen am 29(04), p. 2013.

Campbell, J.Y., 1996. Understanding risk and return. J. Polit. Econ. 104 (2), 298-345.

Cespedes, J., Gonzalez, M., Molina, C.A., 2010. Ownership and capital structure in Latin America. J. Bus. Res. 63, $248-254$.

Chen, J.J., 2004. Determinants of capital structure of Chinese listed firms. J. Bus. Res. 57, 1341-1351.

Cho, S., El Ghoul, S., Guedhami, O., Suh, J., 2014. Creditor rights and capital structure: evidence from international data. J. Corp. Financ. 25, 40-60.

Creane, S., Goyal, R., Mushfiq, M., Sab, R., 2004. Financial sector development in the middle east and north Africa. IMF Working Paper No.04/201. The International Monetary Fund, Washington, DC.

De Jong, A., Kabir, R., Nguyen, T.T., 2008. Capital structure around the world: the roles of firm and country specific determinants. J. Bank. Financ. 32, 1954-1969.

Deesomak, R., Paudyal, K., Pescetto, G., 2004. The determinants of capital structure: evidence from the Asia Pacific region. J. Multinatl. Financ. Manag. 14, 387-405.

Demirguc-Kunt, A., Levine, R., 1999. Bank-Based or Market-Based Financial Systems: Cross-Country Comparisons. Policy Research Working Paper 2143. World Bank, Development Research Group, Washington, D.C.

Demirguc-Kunt, A., Maksimovic, V., 1996. Stock market development and financing choices of firms. World Bank Econ. Rev. 10, 341-369.

Denis, D.J., 2012. The persistent puzzle of corporate capital structure; current challenges and new directions. Financ. Rev. 47 (4), 631-643.

Djankov, S., McLiesh, C., Shleifer, A., 2007. Private credit in 129 countries. J. Financ. Econ. 84, 299-329.

Ebrahim, M., Girma, S., Shah, M., Williams, J., 2014. Dynamic capital structure and political patronage: the case of Malaysia. Int. Rev. Financ. Anal. 31, 117-128.

Fama, E.F., French, K.R., 2002. Testing tradeoff and pecking order predictions about dividends and debt. Rev. Financ. Stud. 15, 1-33.

Fama, E.F., Jensen, M., 1983. The market for corporate control: the scientific evidence. J. Financ. Econ. 11, 5-50.

Fan, J.P.H., Titman, S., Twite, G.J., 2012. An international comparison of capital structure and debt maturity choices. J. Financ. Quant. Anal. $47,23-56$.

Flannery, M.J., Rangan, K.P., 2006. Partial adjustment toward target capital structures. J. Financ. Econ. 79, 469-506. 
Flannery, M.J., Kwan, S.H., Nimalendran, M., 2013. The 2007-2009 financial crisis and bank opaqueness. Journal of Financial Intermediation $22(1), 55-84$.

Frank, M.Z., Goyal, V.K., 2009. Capital structure decisions: which factors are reliably important? Financ. Manag. $38,1-37$.

Getzmann, A., Lang, S., Spremann, K., 2014. Traget capital structure and adjustment speed in Asia. Asia-Pac. J. Financ. Stud. 43, 1-30.

Graham, J.R., 2000. How big are the tax benefits of debt? J. Financ. 55 (5), 1901-1941.

Graham, J., Leary, M., Roberts, M., 2014. A century of capital structure: the leveraging of corporate America. J. Financ. Econ. (forthcoming).

Gungoraydinoglu, A., Öztekin, Ö, 2011. Firm-and country-level determinants of corporate leverage: Some new international evidence. J. Corp. Financ. 17 (5), 1457-1474.

Guyot, A., Lagoarde-Segot, T., Neaime, S., 2014. Foreign shocks and international cost of equity destabilization. Evidence from the MENA region. Emerg. Mark. Rev. 18, 101-122.

Harris, M., Raviv, A., 1991. The theory of capital structure. J. Financ. 46 (1), 297-355.

Haselmann, R., Pistor, K., Vig, V., 2010. How law affects lending. Review of Financial Studies 23 (2), $549-580$.

Huang, R., Ritter, J.R., 2009. Testing theories of capital structure and estimating the speed of adjustment. J. Financ. Quant. Anal. 44 (2), 237-271.

Jappelli, T., Pagano, M., 2002. Information sharing, lending and default: cross country evidence. J. Bank. Financ. 26 (10), $2017-2045$.

Jensen, M.C., 1986. Agency costs of free cash flows, corporate finance and takeovers. Am. Econ. Rev. 76, $323-339$.

Jensen, M.C., Meckling, W.H., 1976. Theory of the firm: managerial behaviour, agency costs and ownership structure. J. Financ. Econ. 3, 305-360.

Kayhan, A., Titman, S., 2007. Firms' histories and their capital structures. J. Financ. Econ. 83 (1), 1-32.

Kurshev, A., Strebulaev, I.A., 2006. Firm Size and Capital Structure (unpublished manuscript).

Leary, M., Roberts, M.R., 2005. Do firms re-balance their capital structures? J. Financ. 60, 2575-2619.

Lemmon, M.L., Robert, M.R., Zender, J.F., 2008. Back to the beginning: persistence and cross-section of corporate capital structure. J. Financ. 63, 1575-1608.

Levine, R., 2002. Bank-based or market-based financial systems: which is better? J. Financ. Intermed. 11 (4), $398-428$.

Lockhart, G.B., 2010. Adjusting to Target Capital Structure: The Effect of Credit Lines. University of Nebraska-Lincoln, Discussion paper.

Mackay, P., Phillips, G.M., 2005. How does industry affect firm financial structure? Rev. Financ. Stud. 18, $1433-1466$.

MacKie-Mason, J.K., 1990. Do taxes affect corporate financing decisions? J. Financ. 45, 1471-1493.

Madeddu, O.S.C.A.R., 2010. The Status of Information Sharing and Credit Reporting Infrastructure in the Middle East and North Africa Region. World Bank Financial Flagship Report Online. Available at: http://siteresourcesworldbank.org/INTMNAREGTOPPOVRED/ Resources/MENAFlagshipCreditRepoIting12i20i10.pdf (accessed October 11, 201 1).

Miao, J., 2005. Optimal capital structure and industry dynamics. J. Financ. 60 (6), 2621-2659.

Modigliani, F., Miller, M.H., 1958. The cost of capital, corporation finance and the theory of investment. Am. Econ. Rev. $261-297$.

Modigiliani, F., Miller, M.H., 1963. Corporate income taxes and the cost of capital: a correction. Am. Econ. Rev. 53 (3), $433-443$.

Morellec, E., 2001. Asset liquidity, capital structure and secured debt. J. Financ. Econ. 6 (2), 173-206.

Myers, S.C., 1977. Determinants of corporate borrowings. J. Financ. Econ. 5 (2), 147-175.

Myers, S.C., 1984. The capital structure puzzle. J. Financ. 39, 575-592.

Myers, S.C., Majluf, N., 1984. Corporate financing and investment decisions when firms have information that investors do not have. J. Financ. Econ. 13, 187-224

Myers, S., Rajan, R., 1998. The paradox of liquidity. Q. J. Econ. 113, 733-771.

Ozkan, A., 2001. Determinants of capital structure and adjustment to long run target: evidence from UK company panel data. J. Bus. Financ. Account. 28, 175-198.

Oztekin, O., Flannery, M.J., 2012. Institutional determinants of capital structure adjustment speeds. J. Financ. Econ. 103, $88-112$.

Rajan, R.G., Zingales, L., 1995. What do we know about capital structure? Some evidence from international data. J. Financ. 50, $1421-1460$.

Rajan, R.G., Zingales, L., 1998. Financial dependence and growth. Am. Econ. Rev. 88, 559-586.

Turk-Ariss, R., 2009. Competitive behavior in middle east and north Africa banking systems. Q. Rev. Econ. Financ. 49 (2), $693-710$.

Windmeijer, F., 2005. A finite sample correction for the variance of linear efficient two-step GMM estimators. Journal of econometrics 126 (1), 25-51.

World Bank Group, 2012. Doing Business 2012. Doing Business in a More Transparent World. The International Bank for Reconstruction and Development, Washington, DC. 